\title{
A REVISION OF EUROPEAN SAXICOLOUS SPECIES OF THE GENUS BUELLIA DE NOT. AND FORMERLY INCLUDED GENERA
}

\author{
Christoph SCHEIDEGGER*
}

\begin{abstract}
A detailed taxonomic survey of the saxicolous European species of Buellia based on a detailed survey and assessment of the important features of the genus is presented. These include the conidia, the anatomy of the exciple, the spore wall pigmentation, ornamentation and internal wall thickening, as well as analysis of the lichen substances. As a result, 36 saxicolous species are recognized, of which Buellia griseosquamulata and $B$. longispora are new taxa and $B$. atrocinerella and $B$. parvula are new combinations. Buellia coniops, $B$. lecideina and $B$. punctata are transferred to the validated genus Amandinea. A key to 43 accepted species of Buellia, Amandinea and Hafellia is included.
\end{abstract}

\section{Introduction}

The genus Buellia was described by De Notaris (1846), who named it after his friend, Esuperanzo Buelli (Leunis 1877). The genus was soon accepted by many early lichenologists (Massalongo 1852; Körber 1855; Fries 1860). Zahlbruckner (1926) subsequently delimited the genus from Rinodina on account of its lecideine apothecia and included both of the crustose genera in the Buelliaceae (Zahlbruckner 1907). Hafellner et al. (1979) distinguished Buellia from Rinodina by differences in the spore type and apothecial margin. Following his circumscription, Buellia was characterized by having spores without any internal wall thickening and possessing lecideine or cryptolecanorine apothecia. Poelt (1973), Henssen \& Jahns (1973) and Hafellner et al. (1979) included the family Buelliaceae in the Physciaceae, thus indicating the close affinities between crustose, foliose and fruticose genera therein (Mayrhofer 1982). Müller \& von Arx (1962) designated B. disciformis as the type species of the genus, which was later accepted and further discussed by Hafellner (1979). Aptroot (1987) outlined a proposal to conserve Buellia against Gassicurtia Fée (Fée 1824).

Buellia remains the least well studied genus of the Physciaceae in Europe, and, with few exceptions, is very poorly known in other parts of the world (North America, Imshaug 1951, 1955; South America, Magnusson 1955; Antarctica, Lamb 1968; India, Singh \& Awasthi 1981; New Zealand, Galloway 1985). Probably because the genus has not less than about 400 (Hawksworth et al. 1983) to 600 taxa (Grummann 1963), a worldwide taxonomic study has not been attempted and even in Central Europe only the corticolous species have been studied in relatively recent times (Schauer 1965).

\footnotetext{
*Swiss Federal Institute for Forest, Snow and Landscape Research, CH-8903 Birmensdorf, Switzerland.
} 
Because many of the classical species characteristics, for example the iodine reaction of the medulla, have been shown to vary greatly, sometimes even within a single thallus (Scheidegger 1987), the aim of this paper was to assess the taxonomic relevance of a range of morphological, anatomical, as well as chemical, characteristics within the genus. A key is presented, followed by concise descriptions of 36 species, which include chorological and ecological data.

\section{Materials and Methods}

Extensive field studies were undertaken in order to study most of the species in nature and to assess variation in their ecology and morphology.

Morphological measurements of external characters were investigated with a binocular Wild M5 with a measuring eyepiece. Internal features, including spore ornamentation were examined at $\times 1000$ (aperture 1.32) with a Leitz Dialux with a drawing tube. Sections $c .15-\mu \mathrm{m}$ thick were cut with a freezing microtome Leitz-1310 with cryomat. Sections of exciple were mounted in an aqueous solution of trichloroacetic acid.

Spore ornamentation was additionally investigated with a Jeol JSM-T 300 scanning electron microscope. A hand section or an entire apothecium was macerated by two tweezers in a small watch glass containing water. Single spores were then separated with a needle from the adhering hymenial gelatinous substance and subsequently transferred in water to an aluminium stub with a small pipette. The aluminium stub was previously coated with a very thin layer of fusion adhesive (Bosch). Following air-drying of the spores, the stubs were heated at $50^{\circ} \mathrm{C}$ for $20 \mathrm{~min}$ to guarantee a good adhesion of the spores to the adhesive. After the stubs had cooled to room temperature, the specimens were sputter-coated with gold and examined at $12-15 \mathrm{kV}$. The descriptions of the spore ornamentation follow Erdtman $(1943,1956)$ and Kremp (1968).

Most specimens investigated were analysed by thin layer chromatography (TLC) following the methods described by Culberson \& Ammann (1979), Culberson et al. (1981), Leuckert (1984), and White $\&$ James (1985). Xanthone-containing species were analysed by double-focusing mass spectrometry (Scheidegger \& Ruef 1988; Ruef 1990). Great care was taken to avoid contamination from adjacent lichen thalli. For all analyses only selected areoles were removed with tweezers from the substratum.

Herbarium specimens were requested from the following institutional and private herbaria (abbreviations according to Holmgren et al. 1990): ANGUC, BERN, BC, BCC, BG, BM, C, CANL, E, FH, GB, GZU, H, HBG, LAUS, LD, LISU, M, MAF, MARSJ, MUB, O, PC, S, STR, STU, SZU, TO, UPS, TUR, TSB, VER, W, WU, Z, ZT, Aptroot (Utrecht), Clerc (Geneva), Hafellner (Graz), Kalb (Neumarkt), Mayrhofer (Graz), Mies (Köln), Poelt (Graz), Renobales (Bilbao), Scheidegger (Birmensdorf), Ullrich (Goslar), Vězda (Brno) and Wunder (Berchtesgaden). A list of the specimens investigated has been lodged at BERN. The abbreviations of the geographical areas from where specimens have been analysed follow Tutin et al. (1964): Al, Albania; Au, Austria; Az, Azores; Be, Belgium and Luxembourg; Bl, Balearic Islands; $\mathrm{Br}$, Britain; Bu, Bulgaria; Co, Corsica; Cr, Crete; Cz, Czechoslovakia; Da, Denmark; Fa, Faeröe Islands; Fe, Finland; Ga, France; Ge, Germany; Gr, Greece; Hb, Ireland; He, Switzerland; Ho, Netherlands; Hs, Spain; Hu, Hungary; Is, Iceland; It, Italy; Ju, Jugoslavia; Lu, Portugal; No, Norway; Po, Poland; Rm, Romania; Rs, former Soviet Union; Sa, Sardinia; Sb, Svalbard (Spitsbergen); Si, Sicily; Su, Sweden; Tu, Turkey.

\section{Results}

\section{Life strategy}

Saxicolous taxa of Buellia show a remarkable variation in their life strategies. Many species are autonomous lichens, 11 European species are lichenicolous lichens (Table 1) and B. adjuncta is a parasymbiont on Lecanora straminea (Hafellner 1979). Only a small number of species are parasites for their entire life cycle (B. adjuncta, B. badia, B. griseosquamulata, B. imshaugii, B. miriquidica) 


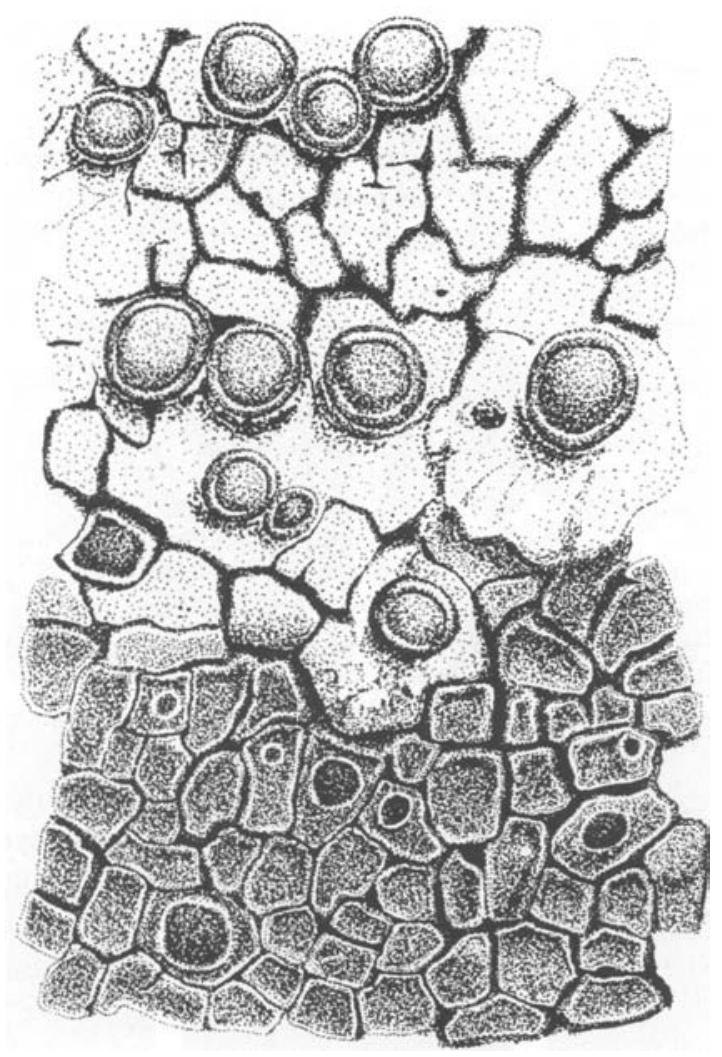

FIG. 1. Buellia griseosquamulata (above) growing as a lichenicolous lichen on B. tirolensis (below). Scale $=1 \mathrm{~mm}$.

(Fig. 1), but some others are only parasitic during a juvenile stage and grow autonomously when forming larger thalli (Table 1). Parasitism can therefore be considered to be a not unusual biological aspect of this genus, at least for the saxicolous species.

\section{Substrata}

Buellia almeriensis is restricted to gypsum, and $B$. caldesiana, B. dispersa and $B$. stellulata may grow on more or less calcareous rocks; all other saxicolous species are confined to siliceous substrata. Buellia dispersa and B. stellulata grow on basic and acid substrata and for these species the influence of a calcareous substratum on the morphology of the thallus is clearly demonstrated by $B$. dispersa (Fig. 2). On siliceous rock, the thallus is areolate to squamulose and slightly placodioid and ochre-coloured (Fig. 2B); when on calcareous rock, the thallus is rimose-cracked to areolate and chalk-white and is never squamulose 
TABLE 1. Parasymbiontic species of Buellia and their hosts

\begin{tabular}{ll}
\hline Species & \\
\hline & \\
B. adjuncta & Lecanora straminea \\
B. badia & Acarospora, Aspicilia, Caloplaca, \\
& Diploschistes, Parmelia s. lat., Rinodina, \\
& Umbilicaria \\
B. concinna & Amandinea coniops, B. uberior, Physcia sp. \\
& Protoparmelia badia \\
B. griseosquamulata & B. tirolensis \\
B. imshaugii & Dimelaena oreina \\
B. jugorum & Placynthiella sp. \\
B. longispora & Aspicilia sp. \\
B. miriquidica & Schaereria fuscocinerea \\
B. sequax & Caloplaca, unidentified crustose lichens \\
B. uberior & Schaereria fuscocinerea \\
B. uberiuscula & Acarospora fuscata \\
\hline
\end{tabular}

$\star$ = regularly parasitic.

(Fig. 2A). The respective thallus anatomies differ mostly in the occurrence of $\mathrm{K}$-insoluble crystals (probably oxalate) in the epinecral layer of thalli on calcareous rocks. K-soluble crystals, probably the lichen products (see below), occur in thalli on both substrata (Figs $2 \mathrm{C}-\mathrm{E}$ ).

\section{Thallus}

In the species investigated, chasmolithic, granular, rimose, areolate, bullate, squamulose and placodioid thalli are distinguished. In chasmolithic lichens the thalli are restricted to very narrow cracks in the substratum, whereas the others are epilithic. Granular thalli have disjunct phycobiont-containing areas on a continuous hypothallus. Rimose thalli have a continuous phycobiont-containing thallus with irregularly arranged, non-reticulate cracks, whereas areolate thalli always have regularly arranged cracks resulting in a reticulate pattern.

Bullate thalli develop from areolate thalli if the areoles grow vertically and finally become stalked, as is regularly found in luxuriant thalli of Amandinea coniops. Squamulose thalli have thalline parts that have only very loose contact with the substratum or that are slightly ascending; placodioid thalli have elongate marginal areoles.

Buellia vilis is mostly chasmolithic and was observed with a thin, superficial, rimose-cracked thallus only once. Buellia leptocline and $B$. sequax are usually epilithic but when on very porous substrata, such as schists, they regularly have chasmolithic thalli. All the other species have epilithic, mostly heteromerous thalli (Fig. 3). Amandinea punctata has a thin granular thallus with isolated to confluent, flat granules. Most species are areolate or rimose-cracked. Due to a great variability in thallus thickness in most species, areolate or rimose thalli often reflect developmental stages, particularly for species that usually have thin thalli. For instance, lime-containing substrata may change an areolate 

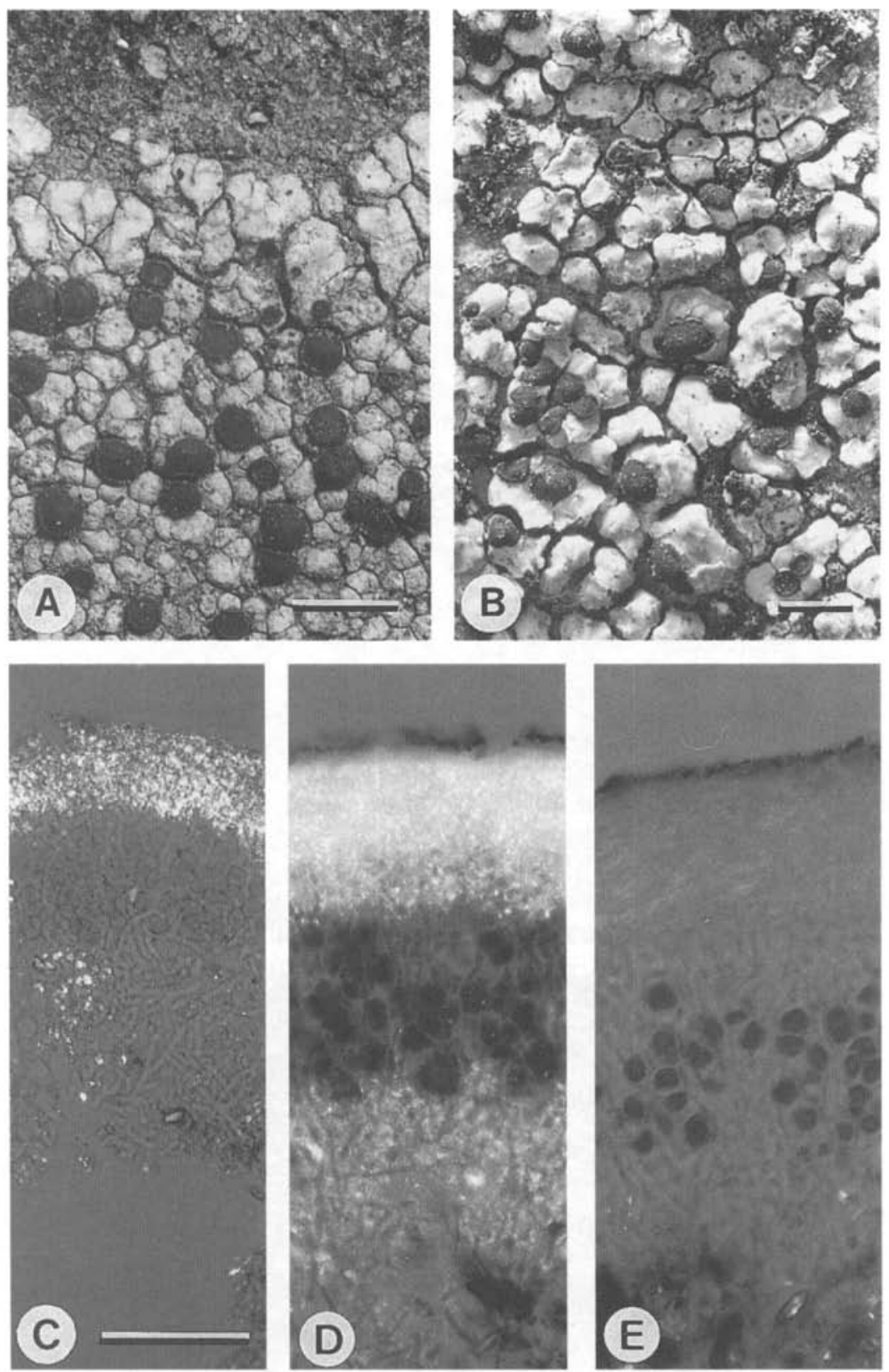

FIG. 2. Influence of the compostition of the substratum on the morphology and anatomy of $B$. dispersa. A, Rimose thallus on lime-containing sandstone (isotype of B. tergestina). B, Areolate to squamulose and slightly placodioid thallus on lime-free siliceous rock (topotype of $B$. squamulata). $\mathrm{C}$, Section through thallus of $\mathbf{A}$ after $\mathrm{K}$ treatment. High amounts of insoluble crystals, presumably of calcium oxalate, are localized in the phaenocortex. Lichen substances were removed by the $\mathrm{K}$ treatment. D, Section through untreated thallus of B. High amounts of crystalline lichen substances are localized in the phenocortex. E, Same section as in D, after K treatment. All crystals were removed by the $\mathrm{K}$ treatment; no insoluble crystals are present in thalli on lime-free substrata. C-E in polarized light. Scales: $A \& B=1 \mathrm{~mm}, C-E=50 \mu \mathrm{m}$. 

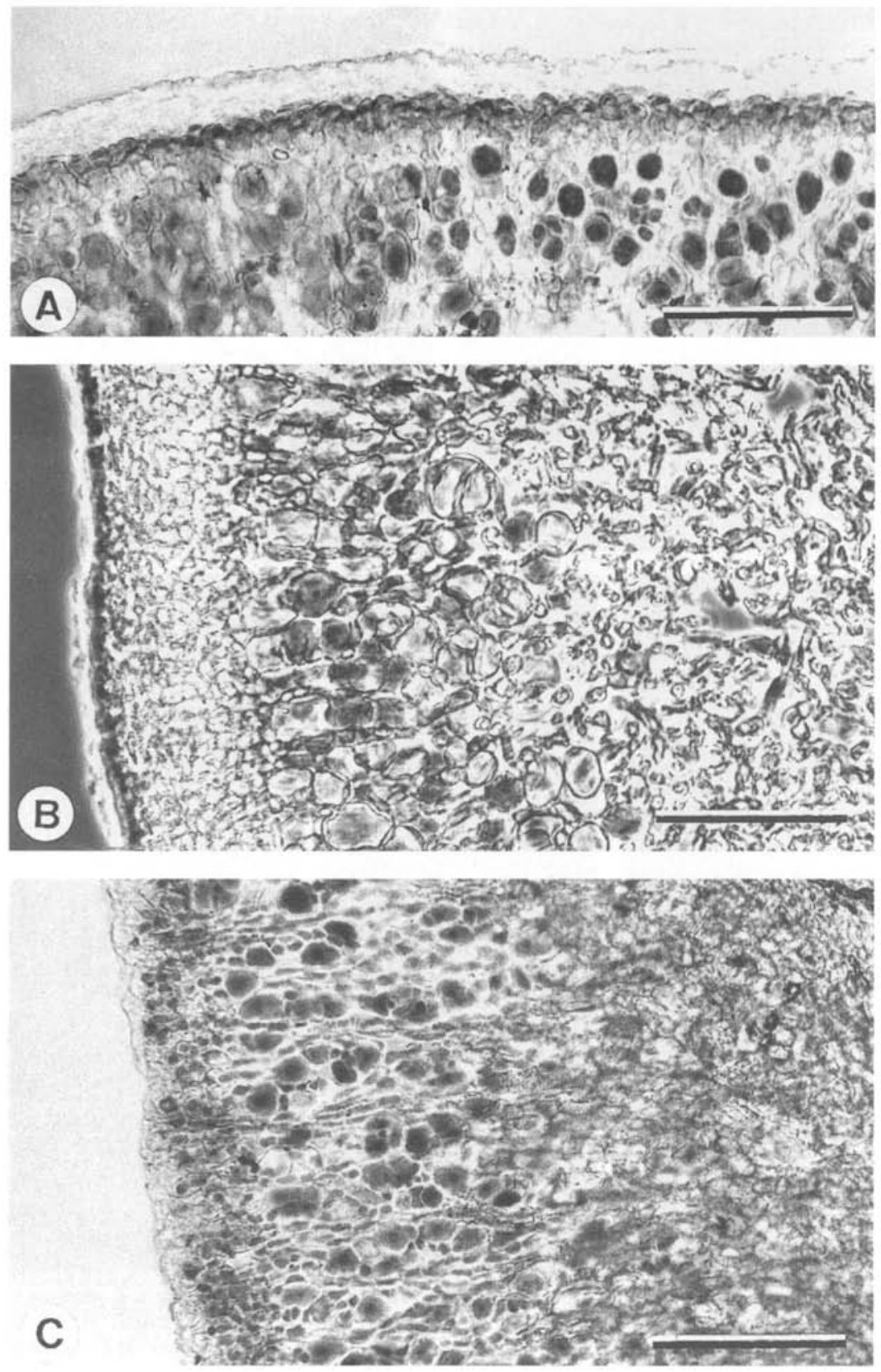

Fig. 3. Different cortical types in Buellia: A, Phenocortex of B. badia with epinecral and thin cortical layer with pigmented and incrassate terminal cells. B, Phenocortex of $B$. dispersa with thick epinecral and thin cortical layer. C, Phenocortex of $B$. spuria with thick cortical and thin epinecral layer. Scale $=50 \mu \mathrm{m}$. 
thallus to rimose, or an areolate thallus may regenerate to rimose after feeding by herbivores. Despite this variability, B. sequax, B. subdisciformis and Hafellia leptoclinoides regularly have rimose-cracked thalli; $B$. aethalea, $B$. ocellata, $B$. miriquidica and $B$. uberior usually have areolate thalli.

The epinecral layer consists of dead and collapsed hyphae in which the cell lumina do not stain with cotton blue. Collapsed algal cell walls can also be observed in this layer in varying amounts in all the species. Although the thickness of this layer is very variable and is often thinned by damage, very thick and cartilaginous epinecral layers, up to $50 \mu \mathrm{m}$, occur in B. badia (Fig. 3A), B. dispersa (Fig. 3B) and related species, whereas in B. spuria (Fig. 3C), $B$. leptocline and related species the epinecral layer is much thinner and always interspersed with very small crystals.

The cortical layer is characterized by anticlinal, cellular hyphae that stain with cotton blue. In some species (Amandinea coniops, A. punctata, Buellia. aethalea (p.p.), B. atrocinerella, B. badia, B. concinna (p.p.), B. fusca, B. miriquidica, $B$. tirolensis, and $B$. uberior) the terminal cells have brownpigmented caps and are clearly swollen. The other species always have unpigmented terminal cells or only a few pigmented cells around apothecia. Both types of cortex belong to the phenocortex (Poelt 1958, 1989) because collapsed algal cells are always found in the epinecral layer (see above). It is possible that particular chemical substances may be an influence in the formation of pigmented cells, as B. ocellata and B.jugorum, which contain xanthones, are the only species of the $B$. aethalea group in which these pigmented cells are absent.

The iodine reaction of the medulla was formerly a widely used taxonomic character at the species level in Buellia (Erichsen 1930, 1957). In some cases this reaction is very constant and closely correlated with other characters, e.g. the chemistry of B. leptocline $(\mathrm{I}+)$, B. saxorum $(\mathrm{I}+)$ and $B$. subdisciformis $(\mathrm{I}-)$; in this and some other species groups this character is taxonomically very reliable. However, in other cases, especially in $B$. aethalea and related species, the reaction may vary greatly, even within a single thallus (Scheidegger 1988), and is therefore of little taxonomic value in these groups.

\section{Pycnidia}

Conidia are always single-celled and thin-walled. They are formed within completely immersed, flask-shaped pycnidia. In B. saxorum and B. subdisciformis, two to a few pycnidia may be regularly confluent (Fig. 4A). The conidiophores are of the Roccella-type (Vobis \& Hawksworth 1981) in $A$. coniops, $A$. lecideina and $A$. punctata, and of the Anaptychia-type in all the species of Buellia and Hafellia where pycnidia have been observed.

The conidia of the last two genera are bacilliform and less than or about $10 \mu \mathrm{m}$ long and $0 \cdot 7-1 \mu \mathrm{m}$ wide (Figs $4 \mathrm{~B}, 5$ ). The length of the bacilliform conidia is a valuable character for separating some closely related species, for example, B. ocellata and B. jugorum (Scheidegger \& Ruef 1988) or taxa with an exciple of leptocline-type (Fig. 5) (see below). By contrast, the three species of Amandinea treated have long, filiform conidia, up to $30 \mu \mathrm{m}$ long (Fig. 4C). Besides having conidiophores of the Roccella-type, it is mainly on the basis of 

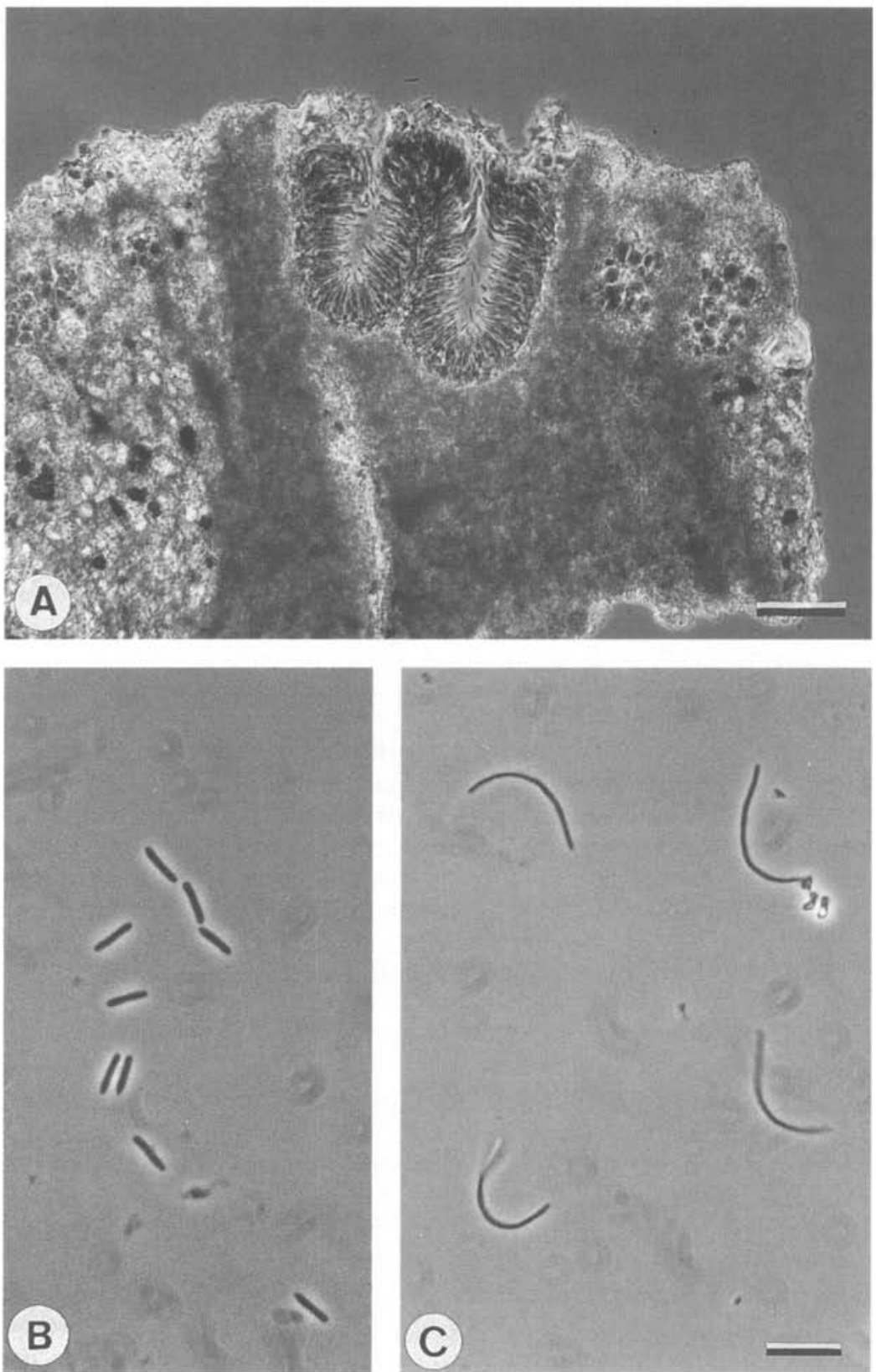

FIg. 4. Conidiomata and conidia of Buellia and Amandinea: A, Confluent pycnidia of $B$. subdisciformis. B, Bacilliform conidia of B. dispersa. C, Filiform conidia of A. lecideina. Scales: $\mathrm{A}=50 \mu \mathrm{m}, \mathrm{B} \& \mathrm{C}=10 \mu \mathrm{m}$. 
A. coniops

A. lecideina

A. punctata

B. subdisciformis

B. fimbriata

B. jugorum

B. longispora

B. sardiniensis

B. saxorum

B. indissimilis

H. leptoclinoides

B. dispersa

B. almeriensis

B. aethalea

B. spuria

B. concinna

B. ocellata

B. badia

B. leptocline

B. uberior

B. miriquidica

B. stellulata

B. vilis

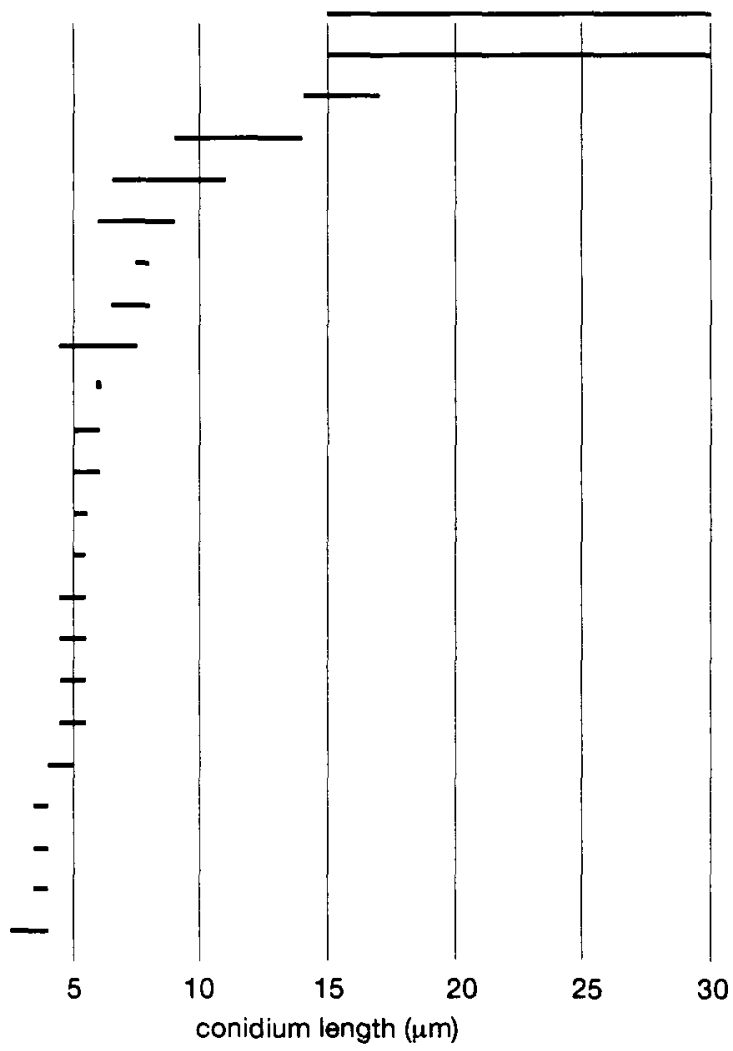

FIG. 5. Range of conidial length in Amandinea, Buellia and Hafellia.

this conidial character that the genus Amandinea (Choisy 1950) is proposed. Only the three European taxa are treated here, but other, non-European species will be discussed elsewhere (Matzer et al. 1994).

\section{Ascomata}

The current delimitation of the genus Buellia includes species with various types of apothecial margins. Cryptolecanorine apothecia are completely immersed in the thallus and have no exiple; lecanorine, biatorine and lecideine apothecia are according to Hawksworth et al. (1983) and Hafellner et al. (1979). The different exciple types discussed below can be examined by the use of cryotome or well-prepared hand sections of younger apothecia. Only exciples that are not coincident with the edge of an areole may be used. The descriptions of plectenchyma follow Korf (1973): textura angularis consists of short-celled, isodiametric hyphae without intercellular spaces, textura intricata has longcelled, interwoven hyphae, whereas in textura oblita the long-celled hyphae are parallel, strongly agglutinated and thick-walled. 


\section{Pigments}

The exciple, hypothecium, paraphysis tips and, in some species, the terminal cells of the thallus cortex, are pigmented. They are distinguished below by their colour in water mounts, their colour changes and solubility in $\mathrm{K}$ and $\mathrm{HNO}_{3}$, and their localization.

Pigment $A$ : green to aeruginose, $\mathrm{K}-, \mathrm{HNO}_{3}+$ red. Always diffuse around pigment B. Rarely localized in the cortex of B. aethalea and B. uberior, frequently in exciples of the aethalea-type and on paraphysis tips. It is also typical for the subhymenium of $B$. ocellata and B.jugorum. This pigment is probably identical to pigment A of Coppins (1983).

Pigment B: dull brown, $\mathrm{K}-, \mathrm{HNO}_{3}-$. In or on the hyphal wall of the paraphysis tips of all species, in the hypothecium of all species, except that of $B$. vilis, also in all coloured cortical cells and in exciples of aethalea- and dispersatypes. This pigment is probably identical to pigment $F$ of Coppins (1983).

Pigment $C$ : dull brown-red to black, $\mathrm{K}-, \mathrm{HNO}_{3}+$ intensifying purple, plus a diffusing brown-red solution. Only in the outer part of the exciple of $B$. vilis.

Pigment D: dull brown, $\mathrm{K}+$ brownish solution, $\mathrm{HNO}_{3}-$. In dispersa-type exciples.

Pigment E: orange-red, $\mathrm{K}+$ red solution, $\mathrm{HNO}_{3}-$. In leptocline-type exciples.

In necrotic parts of thalli further brown pigments may occur but they are not discussed in detail here.

\section{Aethalea-type}

The apothecia are completely immersed to sessile. The disc of the apothecium is plane to hemispherical. The width varies from $0.3 \mathrm{~mm}$ (e.g. B. stellulata) in most cryptolecanorine to zeorine apothecia to about $1 \mathrm{~mm}$ in some species with lecideine apothecia (B. subsquamosa). The margin may be lecanorine (B. ocellata, $B$. parvula and $B$. uberiuscula), zeorine ( $B$. aethalea, $B$.jugorum, B. miriquidica, $B$. stellulata and B. uberior) (Fig. 6C) or lecideine (B. atrocinerella, B. badia, $B$. fusca, $B$. griseosquamulata, $B$. indissimilis, $B$. spuria, $B$. subsquamosa, B. sequax) (Fig. 6A, B \& D). It is mostly prominent and persistent, narrow $(40 \mu \mathrm{m})$ to broad $(100 \mu \mathrm{m})$ and in most species, black. In $B$. atrocinerella, B. fusca and $B$. indissimilis the margin is brown. The plectenchyma of the zeorine apothecia is textura oblita and is anticlinal to the thallus surface. In lecideine apothecia the exciple is radially formed by a textura prismatica or angularis.

The colour of the exciple is the result of pigment $A$ and, in varying amounts, also pigment $B$; this pigmentation is often restricted to the outer part of the exciple only.

Lecideine, cryptolecanorine and zeorine apothecia with the above-mentioned characters represent only different forms of the aethalea-type and formation of a proper margin is probably also regulated in several species by factors such as thallus thickness and damage to the thallus, e.g. by browsing invertebrates (molluscs, insects, mites). 

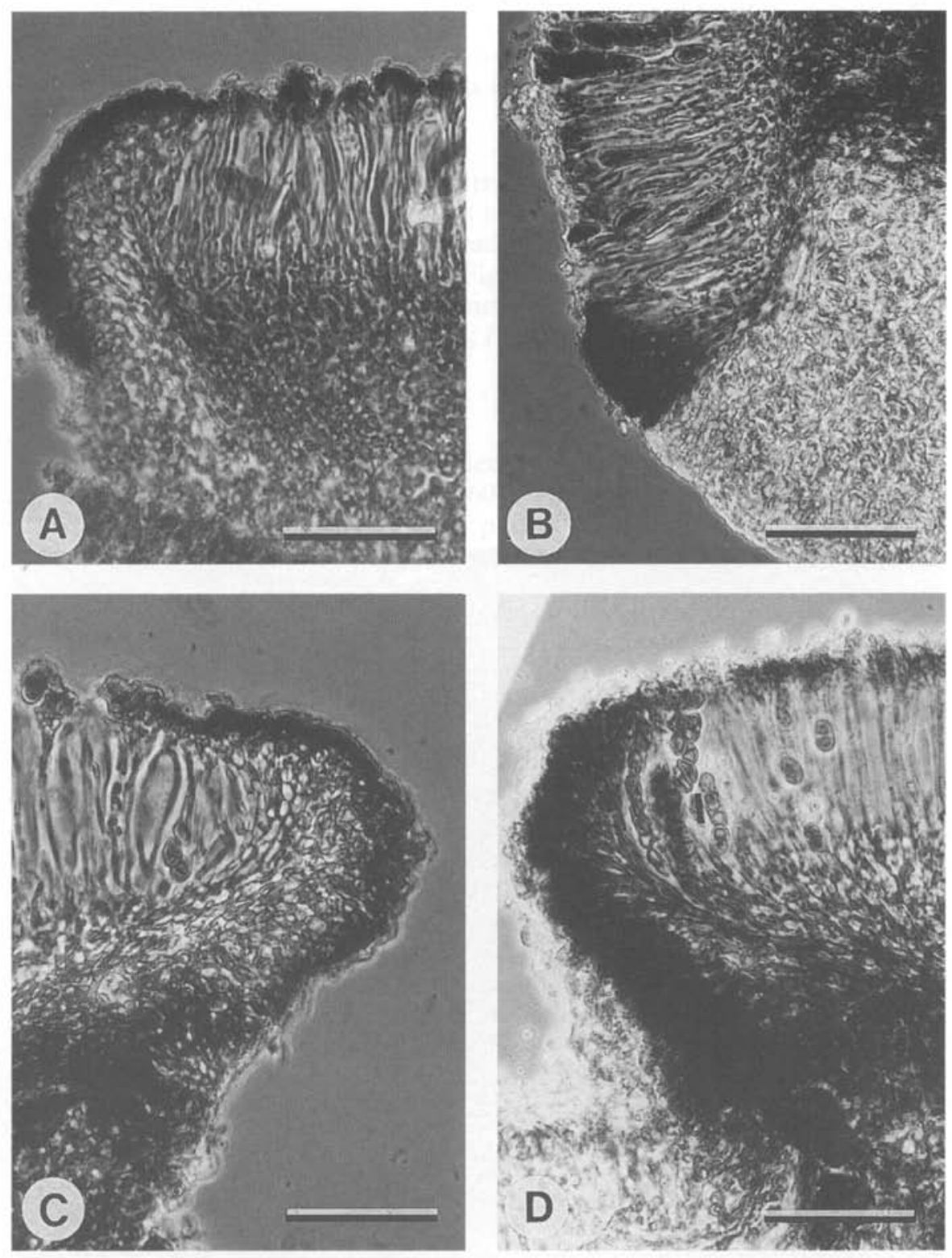

FIG. 6. Exciple of aethalea-type: A, Lecideine apothecium of Amandinea lecideina with hyaline inner part. B, Zeorine apothecium of B. jugorum. C, Lecideine apothecium of Buellia spuria with hyaline inner part. D, Lecideine apothecium of $B$. badia with pigmented inner part. Scale $=50 \mu \mathrm{m}$. 

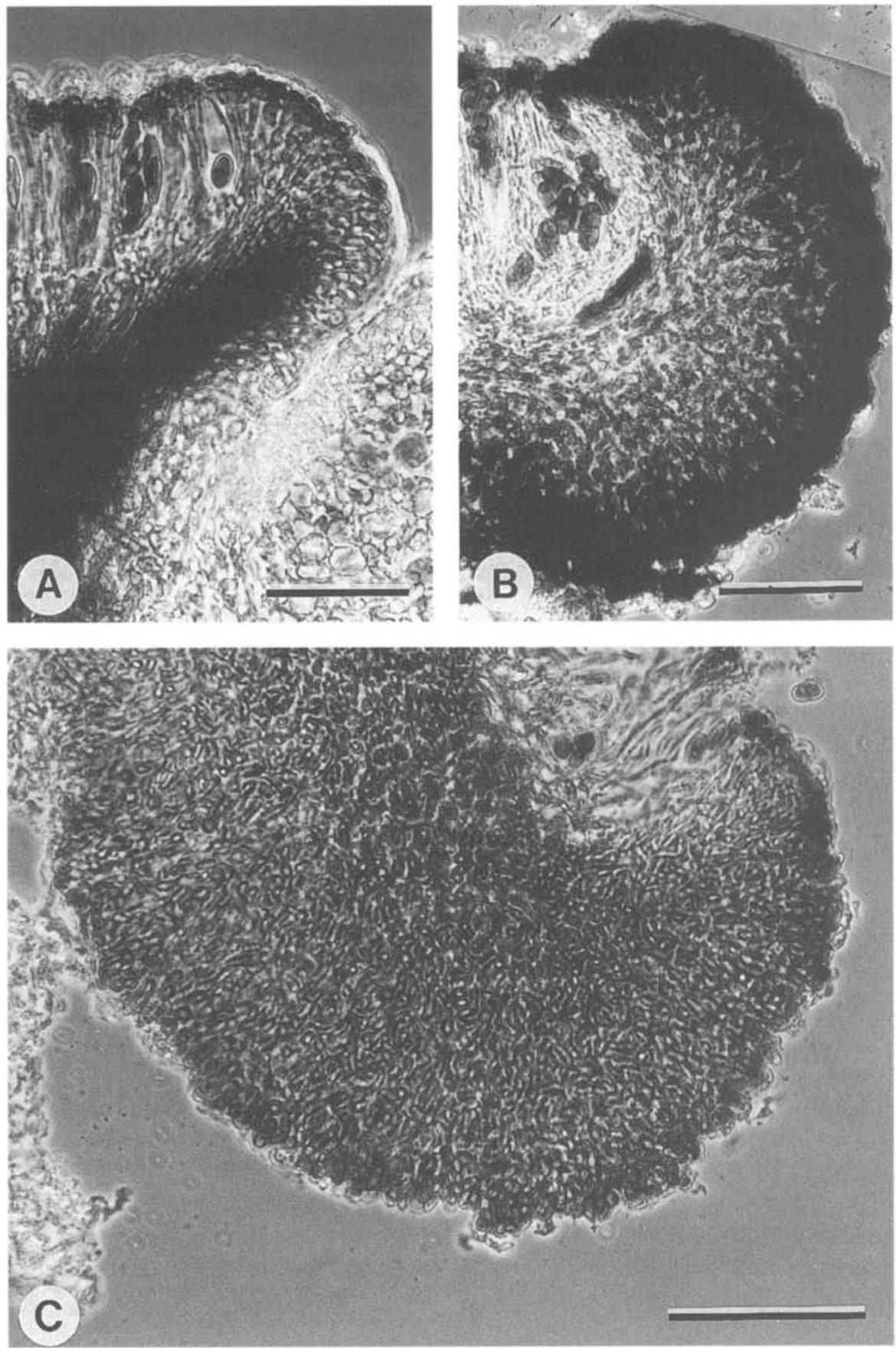

FIG. 7. Exciple-types: A, Dispersa-type of Buellia dispersa with dark inner part and less pigmented outer part of exciple. B, Vilis-type of $B$. vilis with very dark pigmented outer part and almost hyaline inner part. C, Leptocline-type of $B$. leptocline with intricate hyphae homogeneously pigmented throughout. Scale $=50 \mu \mathrm{m}$. 


\section{Vilis-type}

The apothecia are sessile and constricted at their base. The lecideine margin is prominent and persistent. The exciple is radially composed of textura oblita and up to $60 \mu \mathrm{m}$ broad. The outer part of the exciple is markedly coloured with pigment $C$. The inner part is unpigmented and is very strongly amyloid, I+ violet (Fig. 7B); B. vilis is unique to this type.

\section{Dispersa-type}

The apothecia are sessile with a constricted base. The margin is dark brown to black, $60-100 \mu \mathrm{m}$ wide. The disc is mostly plane but in B. excelsa it may become hemispherical. The exciple is radially formed, the inner part of textura oblita, the outer of textura angularis (Fig. 7A). Whereas in younger apothecia only the outer part is coloured with pigments $\mathrm{D}$ and $\mathrm{B}$, older exciples are equally pigmented in their inner and outer parts; $B$. excelsa, B. dispersa, B. longispora and H. leptoclinoides have this type.

\section{Leptocline-type}

The apothecia are sessile and constricted at their base. The margin is black, about $100 \mu \mathrm{m}$ broad (in $B$. almeriensis, $60 \mu \mathrm{m}$ ) and mostly prominent. The disc is plane to strongly convex. The inner part of the exciple is textura intricata, the outer part textura oblita (Fig. 7C). Pigment E is distributed throughout the exciple; $B$. almeriensis, $B$. leptocline, $B$. saxorum, $B$. sardiniensis, and $B$. subdisciformis belong here.

\section{Hymenium}

A pigmented epihymenium is present in every species. According to the presence or absence of pigment B and/or A the colour may vary from brown to olive or green. The apical cells of the paraphyses are always incrassate and coloured with pigment B ('Pigmentkappe' in Kilias 1981). Pigment A, diffusing into the hymenial gelatine ('Pigmenthaube' in Kilias 1981) occurs only in some of the species with apothecia of aethalea-, leptocline- and vilis-types. The amount of pigment $A$, if present, always varies greatly within individual species (Scheidegger 1987).

The hymenium is colourless in all species except B. ocellata and B. jugorum, in which the subhymenium is slightly coloured with pigment A. Hafellia leptoclinoides and $B$. excelsa are the only species that have numerous oil droplets in the hymenium. The oil droplets often exceed $2 \mu \mathrm{m}$ in diameter and are therefore much coarser than those in Lecidella elaeochroma (Ach.) Choisy.

The paraphyses are 1.7-2.5 $\mu \mathrm{m}$ broad in all species. Anastomoses are few and occur mostly in the lower part of the hymenium, whereas branching occurs in or just below the epihymenium. In $B$. dispersa and $B$. excelsa the paraphyses may be easily separated in a squash preparation in water but in the other species they are strongly conglutinate.

The asci are clavate and $30-100 \mu \mathrm{m}$ long. They always belong to the Lecanoratype (Honegger $1978 a, b$ ). They are usually 8 -spored, but in $B$. concinna a few asci with only four spores may be regularly observed. 


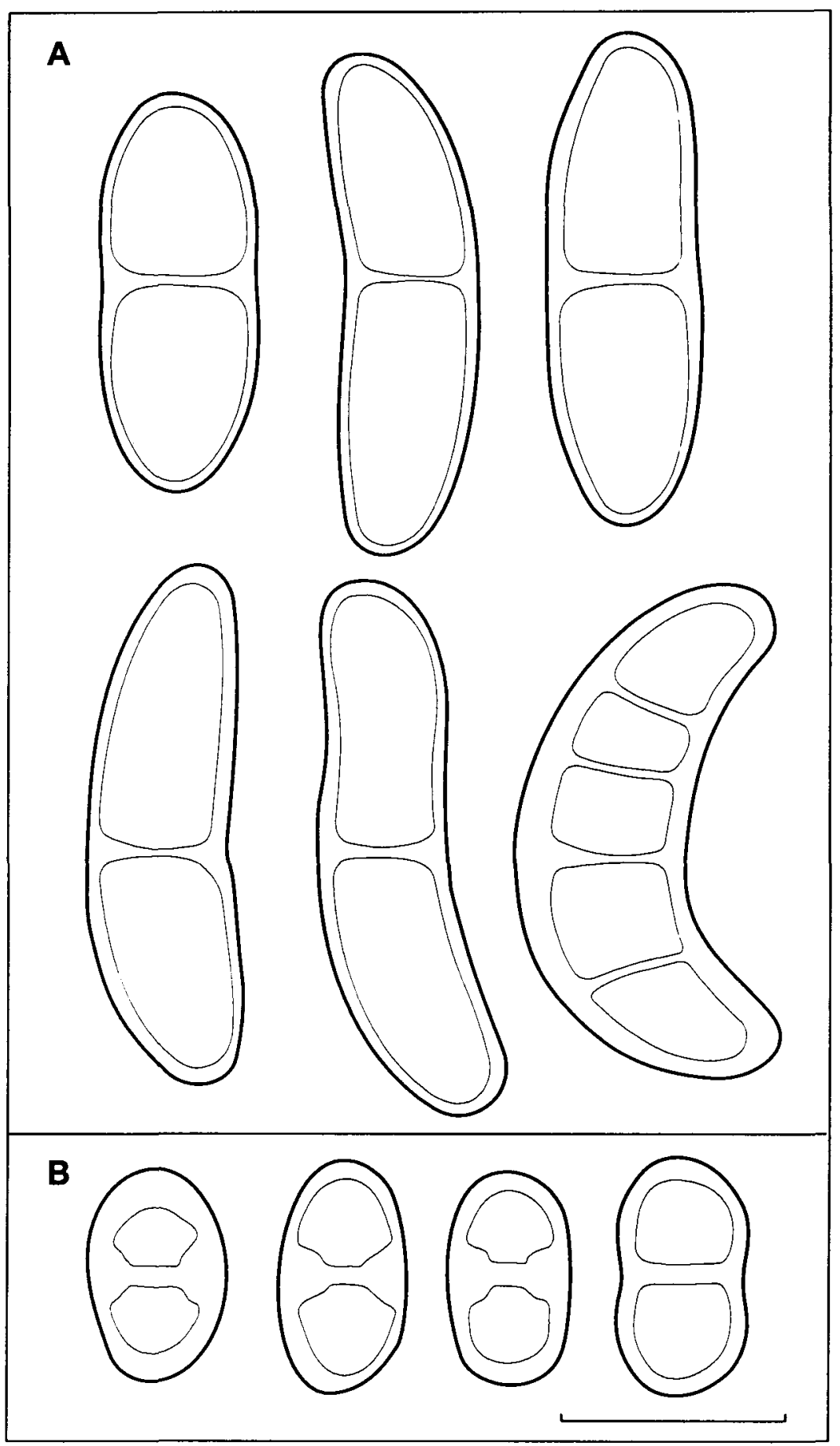

FIG. 8. Mature ascospores of two newly described species. A, Spores of Buellia-type of B. longispora. $\mathrm{B}$, Spores of Physconia-type of B. griseosquamulata. Scale $=10 \mu \mathrm{m}$. 

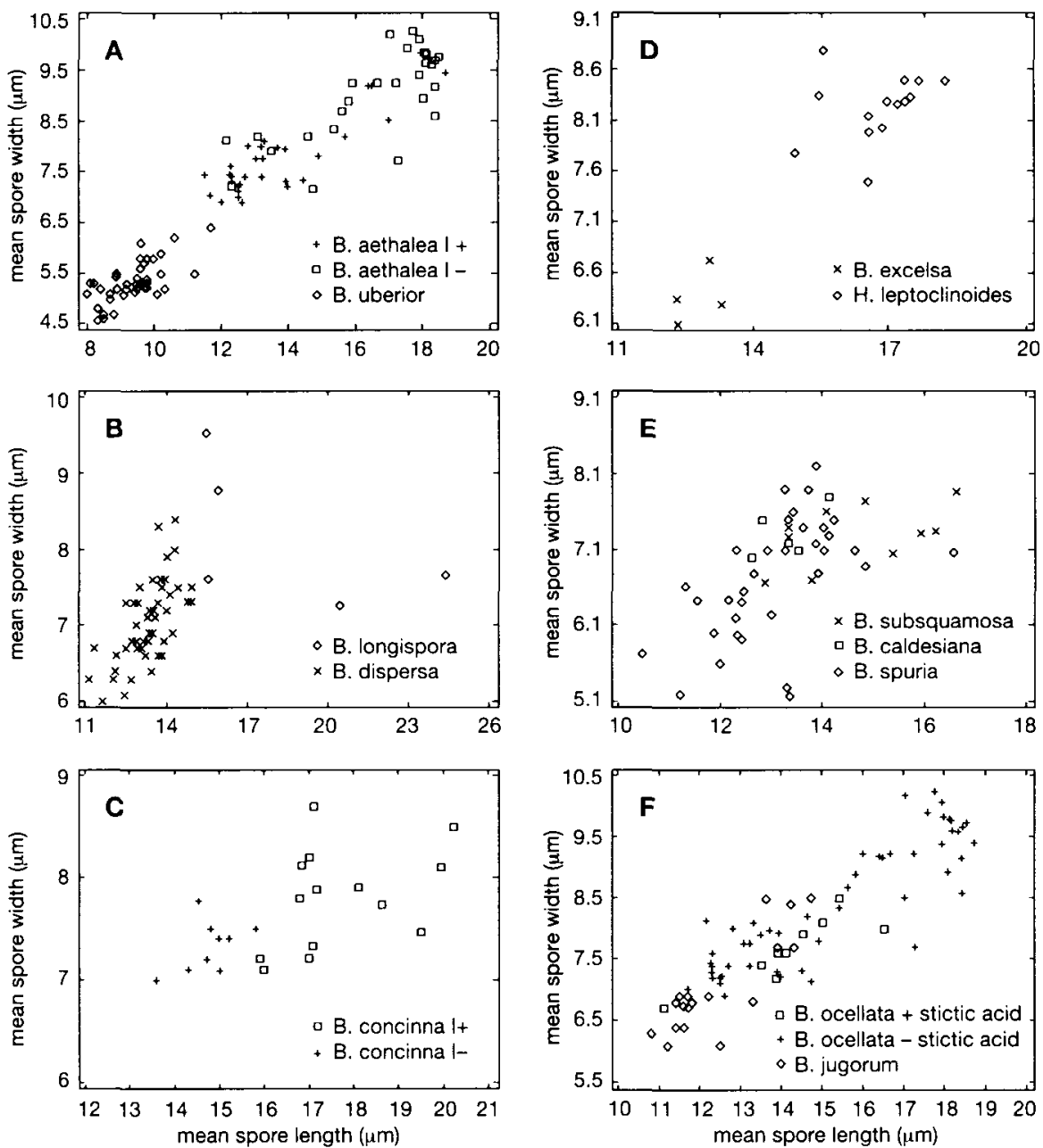

Fig. 9. Mean spore length and width of approx. 30 measurements of selected species of Buellia and Hafellia. A, B. aethalea and B. uberior. B, B. longispora and B. dispersa. C, B. concinna. D, B. excelsa and $H$. leptoclinoides. E, B. subsquamosa, B. caldesiana and B. spuria. F, B. ocellata and B. jugorum.

\section{Spores}

The ascospores of the species discussed here are predominantly one-septate; in most species two- or more-septate spores are exceptional. Only $H$. leptoclinoides, $B$. longispora (Fig. 8A) and B. concinna regularly have spores with 2 , or even 4 , additional, relatively thin trans-septa that only appear in the very late stages of spore ontogeny. Spore length varies from $8 \mu \mathrm{m}$ in $B$. uberior to about $30 \mu \mathrm{m}$ in $B$. longispora (Fig. 8). Variation in spore length and width for a single species is sometimes unusually high, as in B. aethalea (Fig. 9A) or B. concinna (Fig. 9C), whereas it is rather small in species with small spores, such as B. uberior (Fig. 9A). 

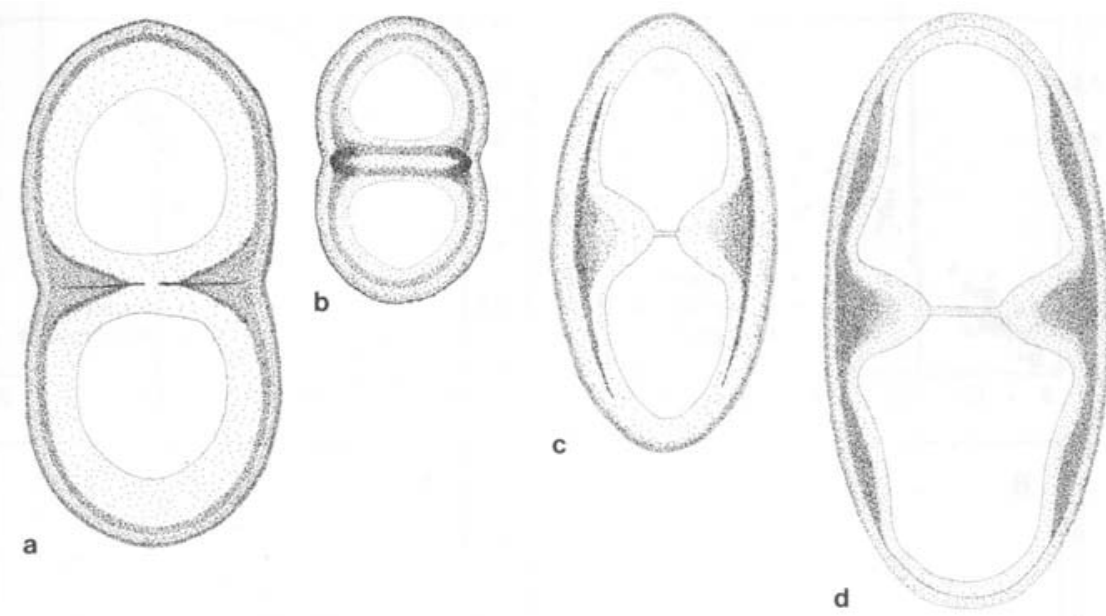

FIG. 10. Spore types of the genera Buellia and Hafellia. W1 (outermost layer) and W3 are dark and W2 and W4 (innermost layer) are not or only slightly pigmented. A-B, Buellia-type without internal wall thickenings. A, B. spuria with diffuse torus. B, B. uberior with intensely pigmented torus. Pigmented wall layers are visible on each side of the septum; the pigmentation is more intense at the periphery, where the two layers fuse. C, Spore of Physconia-type. Juvenile spore of $B$. dispersa with the beginning of pigmentation. Median internal thickening of endospore and relatively thick intermediary layer are visible. D, Spore of Callispora-type. Premature, relatively dark pigmented spore of $H$. leptoclinoides with median and lateral thickenings of the spore wall and the endospore. Scale $=10 \mu \mathrm{m}$

Only in a few cases can spore measurements be used alone to separate taxa, such as $H$. leptoclinoides from $B$. excelsa (Fig. 9D) and $B$. longispora from $B$. dispersa (Fig. 9B). In other related species the spore lengths generally overlap and can therefore be considered only in combination with other characters, such as chemical compounds, for example B. subsquamosa from $B$. spuria (Fig. 9E) and B. ocellata from B. jugorum (Fig. 9F). In the chemotypes of B. ocellata (stictic acid present or absent) (Fig. 9F), amyloid or non-amyloid forms of $B$. concinna (Fig. 9C) and B. stellulata (not shown) with rugulate or psilate spore ornamentation, no significant differences in spore length are present and the respective pairs of taxa are here considered to be conspecific. Amyloid and nonamyloid specimens of $B$. aethalea differ significantly in their respective spore length (Fig. 9A) but are considered here to be conspecific because of numerous intermediate forms with varying amyloid reaction of the thallus medulla.

Various distinctive spore types have been described within the Physciaceae (Poelt \& Mayrhofer 1979; Hafellner et al. 1979; Mayrhofer 1982, 1984a,b) that have proved to be of significant taxonomic value, particularly in the modern revisions of the genus Rinodina. The two major characteristics used for this delimitation of spore type are the internal wall thickening of the immature spore and the nature of the torus. The spore wall of Buellia, as in other genera of the Physciaceae, consists of four layers, as observed by the light microscope (Fig. 10). The outermost layer, W1, is faintly pigmented, W2 is uncoloured, and $\mathrm{W} 3$ is pigmented but with greater intensity than W1. These three layers are 

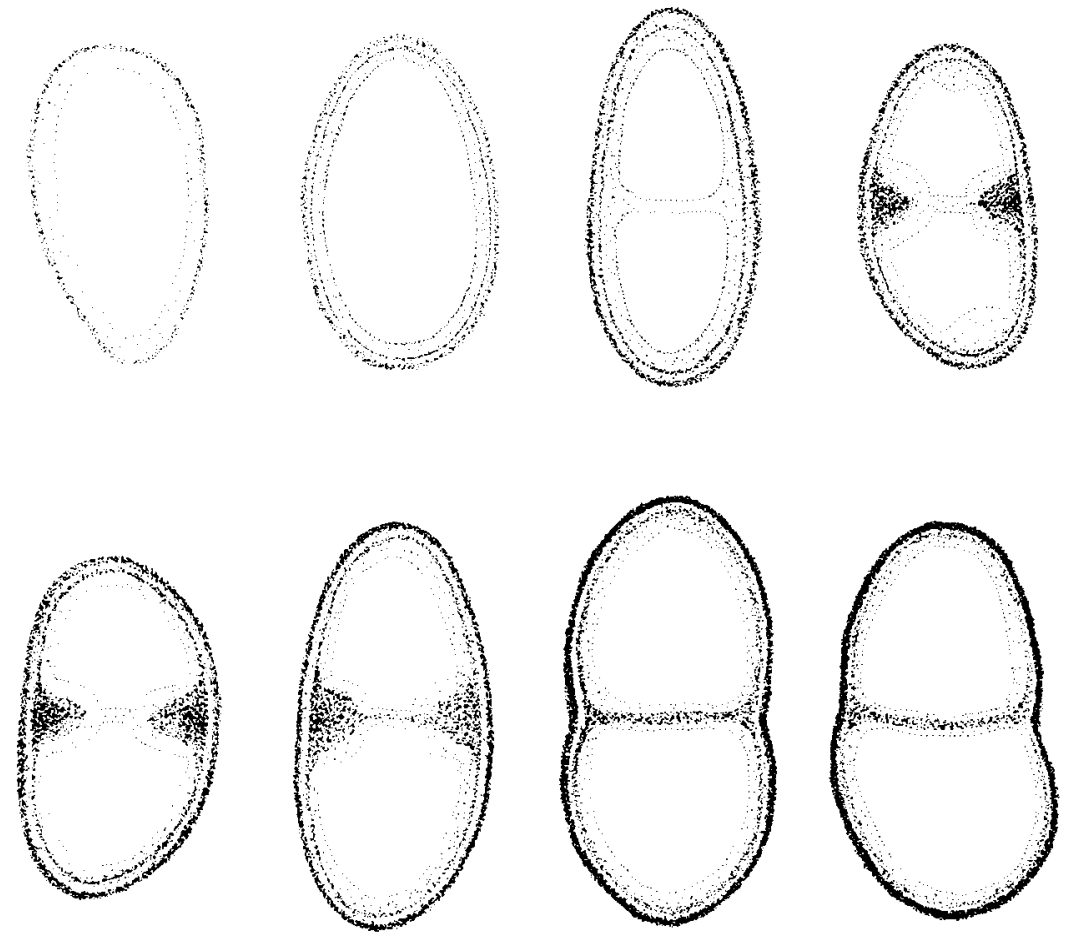

FIG. 11. Spore ontogeny of $B$. leptocline. Non-septate stages are completely unpigmented. After septation, pigmentation of the perispore and the spore wall starts. Short-lived apical thickenings of the endospore and median thickenings of the premature spore are regularly found. The endospore of mature spores is uniformly thick. Scale $=10 \mu \mathrm{m}$.

very thin and may be resolved with light microscopy only after pretreatment of the spores with K. Only B. dispersa (Fig. 10C), B. excelsa and B. longispora have a somewhat wider W2 layer. The innermost layer, W4, is uncoloured and distinctly thicker than all of the outer layers. The septum as well as the internal wall thickening are formed by layers W3 and W4. Comparisons with TEM illustrations (Bellemère \& Letrouit-Galinou 1987) show that W1 corresponds to the perispore, W2 to the intermediate layer, W3 to the spore wall, and W4 to the endospore. At the beginning of their ontogeny the spores are completely colourless and non-septate. Subsequently, a median septum is formed and eventually, pigmentation of both the perispore and the spore wall starts and continues until the spore is mature (Fig. 11).

The intensity of pigmentation of the spores permits a comparison of the different ontogenetic stages of spore development. The torus is a dark belt in the region of the septum and is considered the principal character in the delimitation of spore types in the Physciaceae by Mayrhofer (1982). No TEM photographs have been published in which a torus-like structure could clearly 

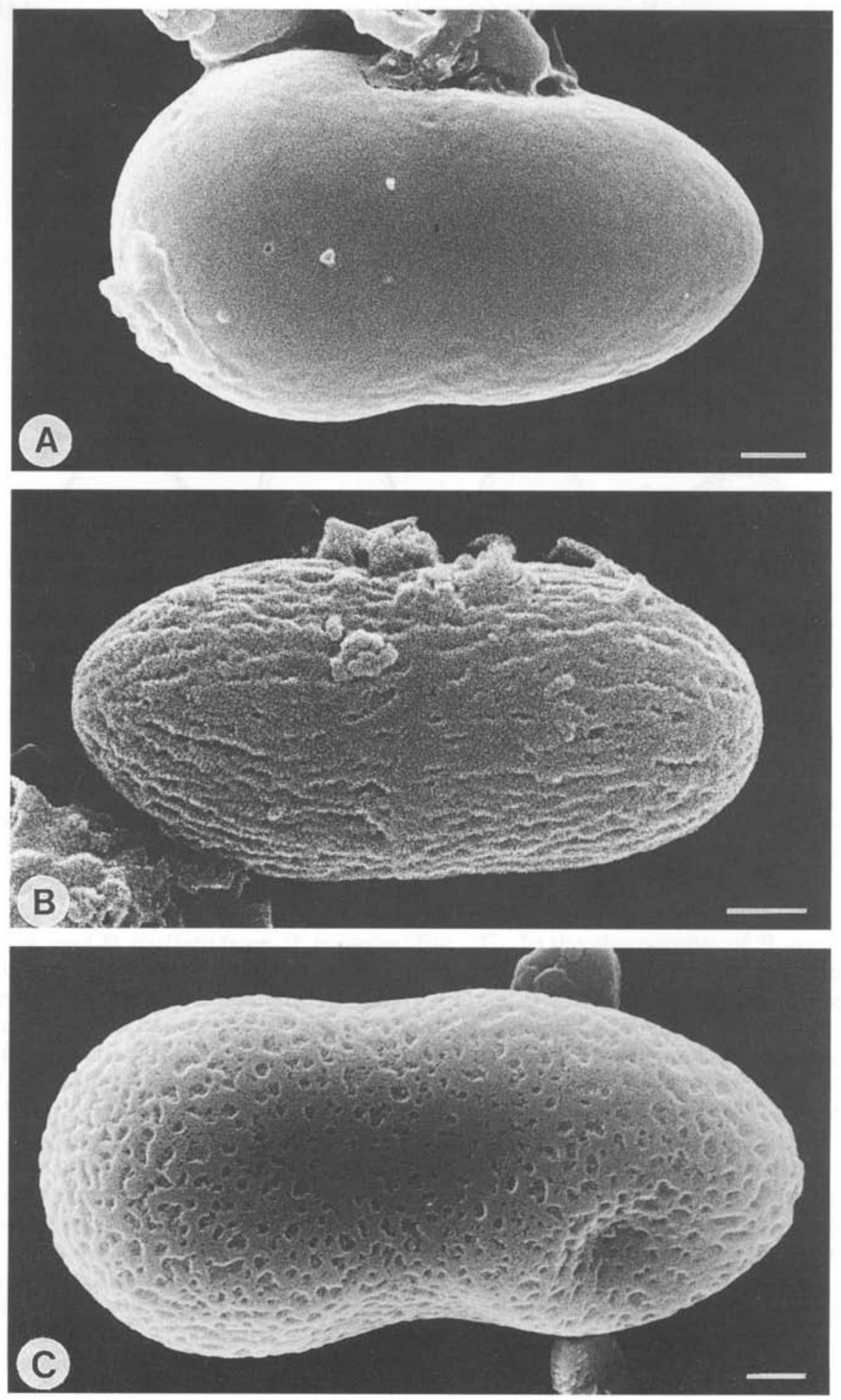
be seen. Based on light microscopy, I consider the torus to be the peripheral part of the spore wall, which belongs to the septum. It is therefore evident that the appearance of the torus during the ontogeny of the spore is highly dependent on the development of the pigmentation of the spore wall. Buellia uberior and $B$. miriquidica both have a very conspicuous and intensely pigmented torus (Fig. 10B). In these species, pigmentation of the spore wall starts in the torus region. First, two faintly coloured rings appear, one at each side of the septum. In the course of further pigmentation the torus region remains the most intensely pigmented part of the spore wall until the mature stage of the spore is reached. At this stage, the two rings are fused at their peripheral part, a feature that has been observed only in these two species but not in $A$. punctata, B. badia or $B$. saxorum, which also have an intensely pigmented torus. On the other hand, in H. leptoclinoides (Fig. 10D), B. dispersa (Fig. 10C), B. spuria (Fig. $10 \mathrm{~A}$ ) and others, the torus region is not more intensely pigmented than the lateral part of the spore wall. In these cases, the torus has a diffuse appearance during the whole process of spore ontogeny.

The relative intensity of the torus compared to the lateral spore wall and its shape varies greatly within the genus but is constant for the species if similar stages of ontogeny are compared. As even closely related species, for instance $B$. aethalea and B. miriquidica, may differ considerably in their torus (Scheidegger 1987 ) and because species with only slight affinities to each other, such as $B$. saxorum and B. badia, have a similar torus, it is concluded that this character may have some taxonomic value at species level but not at a higher rank. Therefore we do not distinguish between Buellia- and Beltraminea- or between Physconia-, Dubyana-and Sicula-types in the following descriptions of spore types.

The spore wall thickening is reported to be the most important character separating Rinodina from Buellia. Therefore, it was surprising during the course of this study to find thickening of the endospore and, to a lesser extent, also of the spore wall in some species regarded as typical taxa belonging to Buellia: $A$. coniops, $B$. dispersa, B. excelsa, B. leptocline, $B$. sardiniensis, $B$. saxorum, $B$. subdisciformis, $H$. leptoclinoides and the newly described $B$. griseosquamulata. All these taxa have median wall thickening, at least during early stages of spore ontogeny, which may be observed with or without pretreatment with $\mathrm{K}$. Only $H$. leptoclinoides has additional lateral thickenings. The median wall thickenings are often much less obvious than those of typical Rinodina species, e.g. R. oxydata (Massal.) Massal. or R. atrocinerea (Hook.) Körber. They are also restricted to a rather short period during spore ontogeny and may, therefore, not be observed in all apothecia of these species. In $B$. leptocline (Fig. 11) the unpigmented spore wall is uniformly thin until the septum is formed. Soon after, very short-lived apical thickenings appear and later disappear, while median thickenings are built up at the same time as spore wall pigmentation commences. The median thickenings are present during the subsequent stages of spore ontogeny and disappear only just before the spores are fully pigmented.

FIG. 12. Ascospore ornamentations. A, psilate spores of B. miriquidica. B, striate spores of $B$. uberior. C, microfoveate spores of $B$. caldesiana. Scale $=1 \mu \mathrm{m}$. 

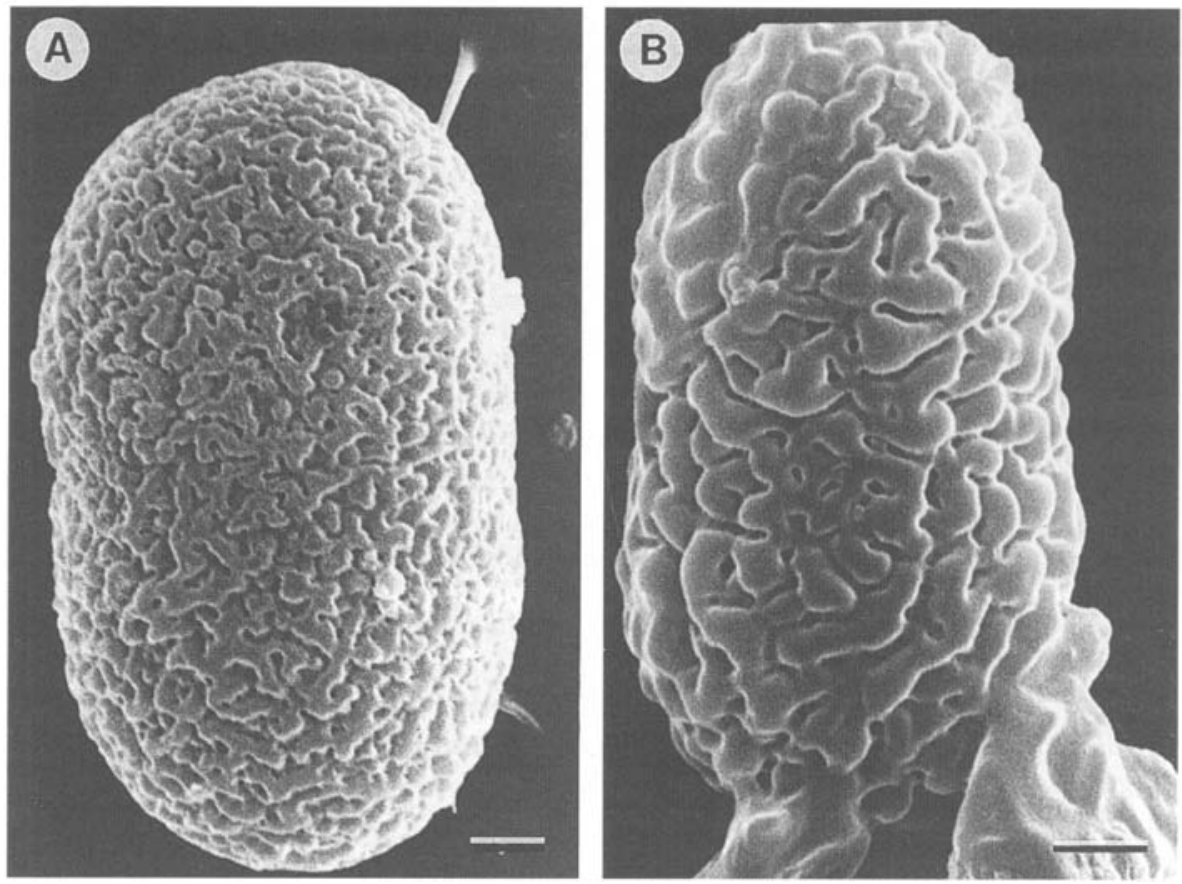

FIG. 13. Ascospore ornamentations. Rugulate ornamentation of $B$. leptocline (A) and B. fimbriata (B). Scale $=1 \mu \mathrm{m}$

Considering the wall differences in thickenings described above, but ignoring the different forms of torus, the following spore types are distinguished:

\section{Buellia-type (incl. Beltraminea-type)}

Spores without any wall thickening during their ontogeny belong to this type (Fig. 10A \& B). Most of the European saxicolous species are included here, including almost all species with an exciple of the aethalea- and vilis-types, as well as $B$. concinna and $B$. longispora with dispersa-type and $B$. almeriensis with leptocline-type; $A$. punctata also belongs here. Also the corticolous $B$. disciformis, the type species of the genus, has spores of this type. Regarding spore shape, constriction of the spore at the septum, spore wall thickness, and torus, this group is very variable. Nevertheless, further division of this type is not justified because these various characteristics form a continuum between well-defined extremes.

\section{Physconia-type (incl. Dubyana- and Sicula-types)}

All species with apothecia of leptocline-type (except of $B$.almeriensis), as well as $A$. coniops and $A$. lecideina, have spores with faint median thickening. This is also true for $B$. dispersa (Fig. 10C) and B. excelsa but they, in contrast to the abovementioned species, have a distinctly thicker intermediary layer and may therefore also have some relationship to the tunicata-type of Rinodina. However, in contrast to R. tunicata Mayrhofer \& Poelt, B. dispersa and B. excelsa lack apical thickening. 
TABLE 2. Spore ornamentation in Amandinea, Buellia and Hafellia

\begin{tabular}{|c|c|c|}
\hline Ornament & Description & Examples \\
\hline Psilate & $\begin{array}{l}\text { Without spore } \\
\text { ornamentation }\end{array}$ & $\begin{array}{l}\text { A. punctata, } B \text {. almeriensis, } B \text {. atrocinerella, } \\
B . \text { badia, B. excelsa, B. fusca, } \\
\text { B. griseosquamulata, }\end{array}$ \\
\hline Striate & $\begin{array}{l}\text { Sculptures elongate, } \\
\text { parallely arranged }\end{array}$ & B. uberior \\
\hline Microrugulate & $\begin{array}{l}\text { Sculptures }<1 \mu \mathrm{m}, \\
\text { circular to elongate } \\
\text { irregularly arranged }\end{array}$ & $\begin{array}{l}\text { A. lecideina, B. aethalea, B. concinna p.p., } \\
\text { B. dispersa, B. ectolechioides, B. imshaugii, } \\
\text { B. jugorum, B. ocellata, B. parvula, } \\
\text { B. sardiniensis, B. saxorum, B. subdisciformis, } \\
\text { B. subsquamosa p.p., B. uberiuscula }\end{array}$ \\
\hline Rugulate & $\begin{array}{l}\text { As microrugulate but } \\
\text { sculptures about } 1 \mu \mathrm{m}\end{array}$ & $\begin{array}{l}\text { A. coniops, } B \text {. concinna p.p., B. fimbriata } \\
\text { B. leptocline, } B \text {. longispora, } B \text {. stellulata p.p., } \\
\text { B. subsquamosa p.p., B. tesserata }\end{array}$ \\
\hline Microfoveate & $\begin{array}{l}\text { Cavities round, }<1 \mu \mathrm{m} \\
\text { scattered }\end{array}$ & B. caldesiana \\
\hline
\end{tabular}

\section{Callispora-type}

The spores of $H$. leptoclinoides belong here (Fig. 10D), although the lateral thickening is less pronounced than in the type species of its genus, $H$. parastata (Nyl.) Kalb (Kalb 1986).

\section{Spore ornamentation}

The nature of spore ornamentation is constant for many taxa and, for several species, has proved to have important taxonomic value at species level (Scheidegger 1987). Spore ornamentation can be distinguished with a light microscope equipped with a lens with an aperture of not less than 1.32 (Table 2). The most remarkable type is probably the striate ornamentation of $B$. uberior (Fig. 12B), but also (micro)rugulate (Fig. 13A \& B) and psilate (Fig. 12A) ornamentation can easily be recognized with light microscopy. The microfoveate ornamentation of the rare B. caldesiana (Fig. 12C) can be distinguished from the microrugulate by carefully focusing through the spore wall and observing the change in brightness of the elements of the ornamentation (Erdtman 1943, 1956). Buellia concinna, B. spuria and B. stellulata have variable ornamentation ranging from rugulate to psilate.

\section{Chemistry}

B-Orcinol para-depsides

Atranorin. Very constant in H. leptoclinoides and in all species of Buellia with leptocline-type exciples (except the non-European B. halonia (Ach.) Tuck. with xanthones). It also occurs in most species with dispersa-type (except $B$. concinna with xanthones), and to a lesser extent also those with aethalea-type exciples (B. spuria, B. stellulata, B. subsquamosa). 
TABLE 3. Lichen products detected in Amandinea, Buellia and Hafellia

\begin{tabular}{|c|c|c|c|c|c|c|c|c|c|c|c|c|c|c|c|c|}
\hline \multirow[b]{2}{*}{ Taxon } & \multicolumn{16}{|c|}{ Substances } \\
\hline & 1 & 2 & 3 & 4 & 5 & 6 & 7 & 8 & 9 & 10 & 11 & 12 & 13 & 14 & 15 & 16 \\
\hline A. coniops & & & & & & & & & & & & & & & & + \\
\hline A. lecideina & & & & & & & & & & & & & & & & + \\
\hline A. punctata & & & & & & & & & & & & & & & & + \\
\hline B. aethalea & & & & & + & & $(+)$ & & & & & & & & & \\
\hline B. almeriensis & + & & & & + & & & & & & & & & & + & \\
\hline B. atrocinerella & & & & & + & & & & & & & & & & & + \\
\hline B. badia & & & & & & & & & & & & & & & & \\
\hline B. caldesiana & + & & & & & & & & & & & & + & & & \\
\hline B. concinna & & & & & & & & & & & & & + & & & \\
\hline B. dispersa & + & + & & & & & & & \pm & + & & & & & & \\
\hline B. excelsa & + & + & & & & & & & & & & & & & & \\
\hline B. ectolechioides & & & & & + & & & & & & & & & & & \\
\hline B. fimbriata & & & & + & & & & & & & & & & & & \\
\hline B. fusca & & & & & & & & & & + & & & & & & \\
\hline B. griseosquamulata & & & & & & & & & & & & & & & & + \\
\hline B. imshaugii & & & & & & & & & & & & & & & & + \\
\hline B. indissimilis & & & & & + & & & & & & & & & + & & \\
\hline B. jugorum & & & & & & & & & & & & & + & & & \\
\hline B. leptocline & + & & & & & & & & & & & & & & & \\
\hline B. longispora & + & & & & + & & + & & & & & & & & & \\
\hline B. miriquidica & & & & & & & & & & & + & & & & & \\
\hline B. ocellata & & & & & & & $(+)$ & & & & & & + & & & \\
\hline B. parvula & & & & & & & & & & & & & & & & + \\
\hline B. sardiniensis & + & & & & + & & & + & & & & & & & & \\
\hline B. saxorum & + & & & & & & & + & & & & & & & & \\
\hline B. sequax & & & & & $(+)$ & & $(+)$ & & & & & & & & & + \\
\hline B. spuria & + & + & & & $(+)$ & & $(+)$ & & & & & & & & & \\
\hline B. stellulata & + & & & & & & & & + & + & & & & & & \\
\hline B. subdisciformis & + & & & & + & & & & & & & & & & & \\
\hline B. subsquamosa & + & & & & & $(+)$ & & & & & & & & & & \\
\hline B. tesserata & & & + & & & & & & & & & & & & & \\
\hline B. tirolensis & & & & & + & & $(+)$ & & & & & & & & & \\
\hline B. uberior & & & & & & & $(+)$ & + & & & & & & & & \\
\hline B. uberiuscula & & & & & + & & & & & & & & & & & \\
\hline B. vilis & & & & & & & & & & & & & & & + & \\
\hline H. leptoclinoides & + & & & & & & & & & & & + & & & & \\
\hline
\end{tabular}

1, Atranorin; 2, chloratranorin; 3, barbatic acid; 4, 3-chlorodivaricatic acid; 5, norstictic acid; 6 , psoromic acid; 7 , stictic acid; 8 , gyrophoric acid; 9 , confluentic acid; 10,2 '-O-methyl perlatolic acid; 11 , miriquidic acid; 12 , placodiolic acid; 13, arthothelin; 14, dichlorolichexanthone; 15, not analysed; 16 , no substances found; + , substance present; \pm , present in small amounts; $(+)$, present in a part of the samples.

Chloratranorin. Only occurs with atranorin. It is found in species with an exciple of dispersa- or aethalea-type but seems to be lacking in species with the leptocline-type.

Barbatic acid. Buellia tesserata contains a substance that is probably barbatic acid. Co-chromatography with barbatic acid was not possible due to the scanty material of $B$. tesserata, which is known only from its type collection. 
3-Chlorodivaricatic acid. The $\mathrm{Rf}$ values are similar to diffractaic acid but the spot of 3-chlorodivaricatic acid is $2 \mathrm{~mm}$ lower in A, $2 \mathrm{~mm}$ higher in B and identical in C. Mass spectrometry showed the following significant peaks $\mathrm{m} / \mathrm{e}$ : $300,298,263,244,228,226,196,178$ (base peak). This substance is regularly found in European and American samples of $B$. fimbriata and Dimelaena radiata (Tuck.) Hale \& Culb.

\section{$\beta$-Orcinol depsidones}

Norstictic acid. Connorstictic acid is always found with this substance. Norstictic acid may occasionally be replaced by stictic acid, e.g. in badly damaged thalli of $B$. aethalea, and also in $B$. tirolensis and B. spuria. In $B$. sequax norstictic acid is found in one of the two respective chemotypes.

Stictic acid. Cryptostictic acid, constictic acid and menegazziaic acid are found with stictic acid in variable relative concentrations. In $B$. uberior (Scheidegger 1987) and in B. ocellata (Scheidegger \& Ruef 1988) stictic acid occurs only in one of the two respective chemotypes and no taxonomic value is given to the occurrence of this substance in these species.

Psoromic acid. Only in B. subsquamosa, occurring in about $50 \%$ of the specimens investigated.

$\beta$-Orcinol tridepside

Gyrophoric acid. Highly constant in B. saxorum, B. sardiniensis and $B$. uberior. Lecanoric acid is always an accessory but in minor amounts.

Orcinol para-depsides

Confluentic acid. This substance always occurs with $2^{\prime}$-O-methylperlatolic acid in various relative amounts. Whereas the spots on the chromatograms of both substances have the same intensity in $B$. stellulata, the spot of confluentic acid is much less intense in $B$. dispersa.

$2^{\prime}-O$-methylperlatolic acid. Highly constant in B. stellulata and occurs in most specimens of $B$. dispersa. In the latter species it is absent in badly damaged specimens and in the samples from Switzerland.

Miriquidic acid. This rather rare substance is constant in B. miriquidica.

Usnic acid and related compounds

Placodiolic acid. Constant in $H$. leptoclinoides. Pseudoplacodiolic acid has not been detected in this species.

Xanthones

Dichlorlichexanthone. Found only in B. indissimilis (Scheidegger \& Ruef 1988). It is accompanied by monochlorlichexanthone. 
Arthothelin. This always occurs with tetrachlornorlichexanthone and dichlornorlichexanthone. In a few specimens additional trichlor- $O$ methylnorlichexanthone was detected but found to be of no taxonomic value (Scheidegger \& Ruef 1988).

\section{Discussion}

This study has revealed many morphological and chemical characters that are valuable for the circumscription of taxa at various hierarchical levels. A cladistic analysis of the species discussed has not yet been carried out as numerous taxa from other continents have not yet been critically studied. However, several characters and/or combinations have led to the acceptance here of a recently described and a neglected genus and to a division of the genus Buellia into species groups.

Long filiform conidia and conidiophores of Roccella-type are known in the Physciaceae from the foliose genus Hyperphyscia (Vainio 1890; Moberg 1977) and now from some elements of the crustose genera Buellia and Rinodina. Based on these characters the genus Amandinea was proposed by Choisy (1950) for $B$. coniops and $B$. punctata. This genus is accepted and validated here, and in addition includes those species of Rinodina with filiform conidia, for example $R$. lecideina. Non-European species in this resurrected genus will be discussed elsewhere.

Hafellia is defined by the callispora spore-type and the presence of placodiolic acid or diploicin.

Exciple types are important for the delimitation of species groups within Buellia. All of these exciple types are also found in non-European species and are therefore likely to be of overall importance in the definitive subdivision of the genus. The aethalea-type is typical for the core of the genus, including the type species of the genus. Furthermore, there is acceptance here of stirps leptocline Th. Fr., stirps vilis (Imshaug 1951) and the species group surrounding $B$. dispersa, which is probably related to stirps retrovertens (Imshaug 1951). The genus Amandinea, as well as species groups of Buellia with leptocline-and dispersatype exciples, includes taxa with spores both of Physconia- and Buellia-types (e.g. Amandinea coniops and $A$. punctata, B. dispersa and B. concinna, B. leptocline and $B$. almeriensis). From this it is concluded that these two spore types have a significant taxonomic value only at the species level in the genus Buellia. Owing to the fact that several species groups include both spores with and without internal wall thickenings, the distinction between Rinodina (with thickenings) and Buellia (without thickenings) is no longer tenable and a new circumscription of these two currently highly heterogeneous genera is now needed.

\section{Key to the Saxicolous Species with One-septate Spores}

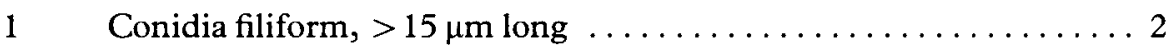

Conidia bacilliform, $<12 \mu \mathrm{m}$ long $\ldots \ldots \ldots \ldots \ldots \ldots \ldots \ldots$

2(1) Thallus areolate, sometimes becoming bullate, $>0.5 \mathrm{~mm}$ thick, brownish. Spores rugulate. Maritime ..... Amandinea coniops

Thallus granular to rimose, $<0.3 \mathrm{~mm}$ thick, whitish to greyish. Spores microrugulate or psilate. Maritime or not $\ldots \ldots \ldots \ldots \ldots \ldots$ 
3(2) Spores with median wall thickenings, microrugulate. Mostly maritime, rarely alpine $\ldots \ldots \ldots \ldots \ldots \ldots \ldots \ldots \ldots \ldots \ldots \ldots \ldots \ldots \ldots$. lecideina Spores without median wall thickenings, psilate. Widely distributed ..

A. punctata s.lat.

4(1) Parasymbiont on Lecanora straminea. [Not treated here, see Hafellner (1979)] ................... Buellia adjuncta Th. Fr.

Lichenized, not on Lecanora straminea ............. 5

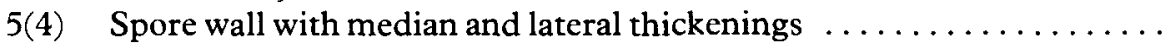

Hafellia leptoclinoides

Spore wall without lateral thickenings, with or without apical and median thickenings $\ldots \ldots \ldots \ldots \ldots \ldots \ldots \ldots \ldots \ldots \ldots \ldots \ldots \ldots \ldots \ldots$

6(5) Apothecia cryptolecanorine, or if lecideine, then exciple of aethalea-

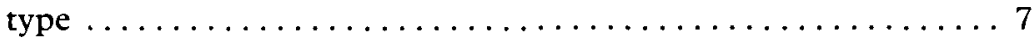

Apothecia lecideine, excipula of leptocline-, dispersa- or vilis-type . . 34

7(6) Thallus yellowish, $\mathrm{C}+$ persistent orange (with xanthones) $\ldots \ldots 8$

Thallus whitish, greyish or brownish, $\mathrm{C}$ - or $\mathrm{C}+\mathrm{red}$ (without xanthones)

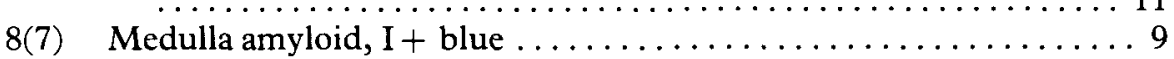

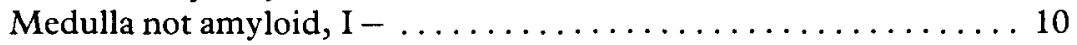

9(8) Spore ornamentation microfoveate. Thallus $\mathrm{K}+$ yellow B. caldesiana Spore ornamentation psilate. Thallus $\mathrm{K}+$ yellow to red (norstictic acid)

B. indissimilis

10(8) Conidia 4.5-5.5 $\mu \mathrm{m}$ long. Thallus rimose to areolate, marginal areoles uniform, not elongate. Widely distributed lowland species in Central Europe ....................... ocellata

Conidia $6-9 \mu \mathrm{m}$ long. Thallus of scattered areoles or continuously areolate, marginal areoles enlarged, elongate. Alpine . . B. jugorum

$11(7)$ Thallus parasitic on Schaereria fuscocinerea . . . . . . . . . 12

Thallus not associated with Schaereria fuscocinerea ......... 13

12(11) Spore ornamentation striate; gyrophoric acid . . . . . . B. uberior Spore ornamentation psilate; miriquidic acid ..... B. miriquidica

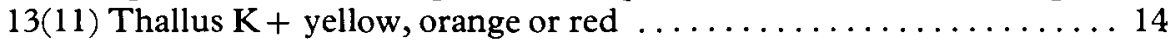

Thallus $\mathrm{K}$ - or thallus not visible $\ldots \ldots \ldots \ldots \ldots \ldots \ldots \ldots \ldots$

14(13) Atranorin present. Thallus whitish, apothecia often $>0.5 \mathrm{~mm}$ diam. or if $<0.5 \mathrm{~mm}$ diam., then immersed; epihymenium green ... . . 15

Atranorin absent. Thallus brownish or greyish, if whitish then $\mathrm{K}-$ (without lichen acids) or $\mathrm{K}+$ red (norstictic acid). Apothecia often $<0.5$ mm diam. . . . . . . . . . . . . . . . . . . 21

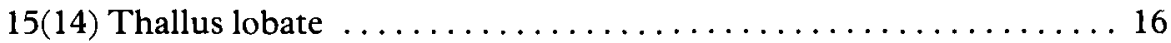

Thallus not lobate . . . . . . . . . . . . . . . . . 19

16(15) Thallus sorediate, spore wall with apical and median thickening [Not treated here, see Llimona et al. (1976)] . . . . . . . . . . Diploicia

Thallus not sorediate, spore walls without thickenings. Terricolous species of $B$. epigaea group, sometimes also on rocks. [Not treated

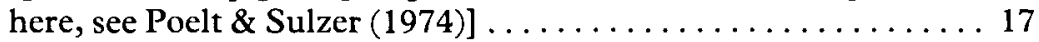

17(16) Asci 4-spored, spore ornamentation psilate . . . . . . . . . . . . .

B. asterella Poelt \& M. Sulzer

Asci 8-spored, spore ornamentation psilate or microrugulate . . . 18 
18(17) Spore ornamentation psilate. On gypsum in the Mediterranean area . .

B. zoharyi Galun

Spore ornamentation microrugulate. On slightly calcareous soil in

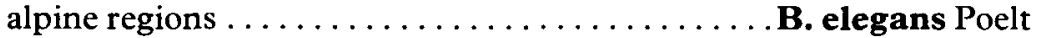

19(15) Medulla I-. Apothecia $<0.5 \mathrm{~mm}$, thallus $\mathrm{K}+$ yellow (atranorin and 2 '$O$-methylperlatolic acid) $\ldots \ldots \ldots \ldots \ldots \ldots \ldots \ldots$. stellulata

Medulla I + violet. Apothecia $>0.5 \mathrm{~mm}$ diam. or if $<0.5 \mathrm{~mm}$, thallus

$\mathrm{K}+$ orange (stictic and/or norstictic acid) ............ 20

20(19) Spores $10-15 \mu \mathrm{m}$ long, spore wall brown, psilate to microrugulate. Medulla $\mathrm{K}+$ yellow to orange or red, $\mathrm{P}+$ orange (atranorin and stictic or norstictic acid) ................... spuria Spores 13-17 $\mu \mathrm{m}$, long spore wall very dark brown, rugulate. Medulla $\mathbf{K}-, \mathbf{P}+$ red (atranorin, psoromic acid) ....... subsquamosa

21(15) Spores psilate . . . . . . . . . . . . . . . . . . . 22

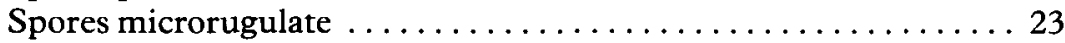

22(21) Thallus areolate, dark brown, often glossy. Areoles often white marginate. Apothecia cryptolecanorine ........... tirolensis Thallus rimose, pale brown, matt. Apothecia lecideine B.atrocinerella

23(21) Apothecia sessile, constricted at the base . . . . . . B. sequax p.p.

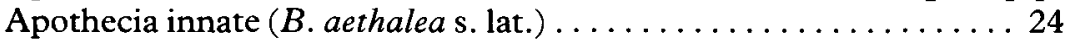

24(23) Areolae scattered, conical . . . . . . . . . . . . . . B. ectolechioides Areolae crowded, thallus rimose, areolate or slightly squamulose, flattened or somewhat convex $\ldots \ldots \ldots \ldots \ldots \ldots \ldots \ldots \ldots$

25(24) Thallus squamulose. On Acarospora fuscata in nutrient-rich alpine

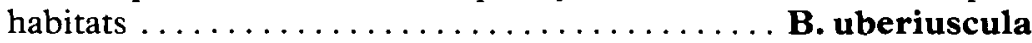
Thallus not squamulose; evenly areolate or \pm rimose, not on $A$. fuscata

B. aethalea

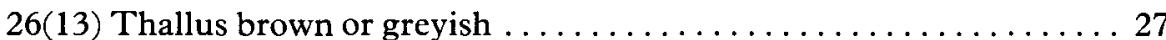

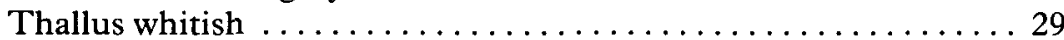

27(26) Thallus squamose, overgrowing other lichens . . . . . . B. badia Thallus areolate, not overgrowing other lichens ......... 28

28(27) Apothecia sessile, lecideine ......... Amandinea punctata s. lat. Apothecia immersed, biatorine or cryptolecanorine . . . . . . B. fusca

29(26) On rocks incrustated with calcareous soil. [Not treated here, see Poelt \& Sulzer (1974)] . . . . . . . . . . . B. epigaea (Pers.) Tuck.

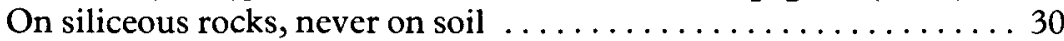

30(29) Thallus whitish, apothecial disc convex to hemispherical . . . . . 31 Thallus greyish or endolithic, apothecial disc plane . . . . . . 32

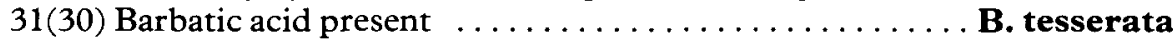
3-Chlorodivaricatic acid present ............ Bimbriata

32(30) Apothecia lecanorine or cryptolecanorine. Alpine . . . . B. parvula Apothecia lecideine, sessile . .................... 33

33(32) Spores 9-11 $\mu \mathrm{m}$ long, with median wall thickenings. Thallus areolate to slightly squamulose. Growing over $B$. tirolensis

B. griseosquamulata

Spores 11-13.5 $\mu \mathrm{m}$ long, without median wall thickenings. Thallus rimose to areolate. Autonomous lichen or growing over Caloplaca ..

B. sequax p.p. 
34(6) Outer part of exciple reddish black, $\mathrm{K}-$, hyaline in inner part. Hypothecium pale, strongly amyloid, I+ blue-violet . . . . . B. vilis

Exciple not hyaline in inner part and reddish black in outer part, hypothecium dark or if pale then not amyloid, $I-\ldots \ldots \ldots 35$

35(34) Exciple of intricate hyphae, orange-brown in thin sections, pigment soluble in $\mathrm{K}$, diffusing orange (except for $B$. almeriensis) (leptocline-

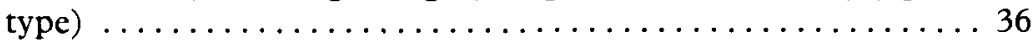

Exciple of hyphae of textura oblita or textura angularis, without orange

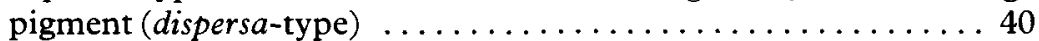

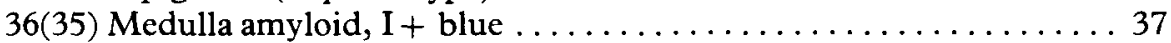

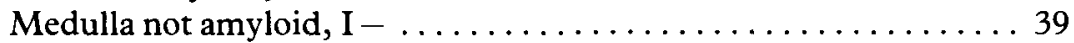

$37(36)$ Thallus $\mathrm{C}+$ red (gyrophoric acid) $\ldots \ldots \ldots \ldots \ldots \ldots \ldots \ldots \ldots \ldots \ldots$

Thallus $\mathrm{C}-\ldots \ldots \ldots \ldots \ldots \ldots \ldots \ldots \ldots \ldots \ldots \ldots$. leptocline

38(37) Thallus $\mathrm{K}+$ red crystals (atranorin and norstictic acid) ...........

B. sardiniensis

Thallus $\mathrm{K}+$ yellow (atranorin) $\ldots \ldots \ldots \ldots \ldots \ldots$ B. saxorum

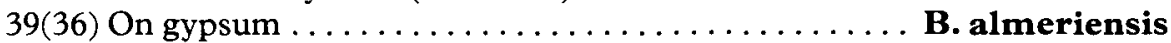

On siliceous rocks $\ldots \ldots \ldots \ldots \ldots \ldots \ldots \ldots \ldots$. subdisciformis

40(35) Thallus on Dimeleana oreina . . . . . . . . . B. imshaugii

Thallus autonomous or growing over various lichens $\ldots \ldots \ldots 41$

41(40) Hymenium with numerous oil droplets . . . . . . . B. excelsa

Hymenium without oil droplets $\ldots \ldots \ldots \ldots \ldots \ldots \ldots \ldots \ldots \ldots$

42(41) Thallus $\mathrm{K}+$ red crystals (norstictic acid and atranorin), spores rugulate, $17-25 \mu \mathrm{m}$ long $\ldots \ldots \ldots \ldots \ldots \ldots \ldots \ldots \ldots$. longispora

Thallus $\mathrm{K}+$ yellow (2'-O-methylperlatolic acid and atranorin), spores psilate to microrugulate, $11-16 \mu \mathrm{m}$ long $\ldots \ldots \ldots \ldots$. . dispersa

\section{Short descriptions of the taxa}

\section{Amandinea}

\section{Amandinea Choisy ex Scheidegger \& Mayrh. gen. nov.}

\section{Amandinea Choisy, Bull. Mens. Soc. Linn. Lyon 19: 16 (1950), nom. inval. (Art. 36.1).}

Ascomycetes lichenisati. Thallus crustaceus algas chlorococcales continens. Apothecia lecideina vel lecanorina. Sporae 8nae, fuscae, 1-septatae. Pycnidia immersa, innata vel sessilia. Conidia filiformia, arcuata.

Typus: Lecidea coniops Wahlenb. in Ach.

Thallus crustose, rimose, areolate to bullate. Medulla $\mathrm{I}-$, not amyloid. Apothecia lecanorine or lecideine, innate to sessile with broad or constricted base. Ascospores brown, one-septate, with or without median spore wall thickenings, often with rugulate ornamentation. Pycnidia often present; conidia filiform, curved, up to $30 \mu \mathrm{m}$ long.

Chemistry: Rarely norstictic acid, more often no chemical compounds detectable by TLC. A more detailed revision of the non-European species is currently in preparation. 


\section{Amandinea coniops (Wahlenb. in Ach.) Choisy ex Scheidegger \& Mayrh. comb. nov.}

Basionym: Lecidea coniops Wahlenb. in Ach., Meth. Lich., Suppl.: 8 (1803).-Buellia coniops (Wahlenb. in Ach.) Th. Fr., Nova Acta Reg. Soc. Scient. Upsal. Ser. 3, 3: 331 (1860). Type: Norway. Finmark. Altenfjord, Baskop. April 1802, Wahlenberg (UPS!-holotypus).

Thallus areolate to bullate, brown, medulla I-, not amyloid. Apothecia biatorine to lecideine, $0.5-0.8 \mathrm{~mm}$ diam., broadly sessile, disc plane to convex, margin thick, persistent. Exciple aethalea-type. Hymenium without oil droplets, 58-80 $\mu \mathrm{m}$ high, epihymenium brown, hypothecium dark brown. Ascospores broadly oblong, constricted at septum, 13-18 $\times 7-9.5 \mu \mathrm{m}$, Physconia-type, ornamentation rugulate. Conidia filiform, curved, $15-30 \mu \mathrm{m}$ long.

\section{Chemistry: No substances found.}

Taxonomy: Amandinea coniops differs from $A$. lecideina in the thicker thallus, the bigger apothecia and slightly longer and broader spores. In most cases $A$. coniops is easily recognizable by its bullate thallus and filiform conidia. In southern Scandinavia, however, the species may resemble $A$. lecideina and could be confused with this species. Collections with both species growing side by side would be useful for delimiting the two taxa.

Ecology and distribution: Confined to granitic rocks in boreal to arctic sea coasts. The species is widely distributed in Northern Europe south to Ireland, but also occurs in Siberia, Greenland, Alaska (Imshaug 1951), Canada and Antarctica (Lamb 1968). Collections from inland habitats are incorrect determinations. European specimens have been studied from: $\mathrm{Br}, \mathrm{Fe}, \mathrm{Hb}$, $\mathrm{No}, \mathrm{Sb}, \mathrm{Su}$.

\section{Amandinea lecideina (Mayrh. \& Poelt) Scheidegger \& Mayrh. comb. nov.}

Rinodina lecideina Mayrh. \& Poelt, Bibl. Lich. 12: 112 (1979). Type: Eire, Co. Ciarrai/Kerry, Corca Dhuibhne/Dingle-peninsula,Umgebung des Weilers Ballyoughteragh N Baile an Fheirtearaigh/ Ballyferriter, an Weidemauern, August 1978, Poelt (GZU!-holotype).

Buellia punctata f. crassior (Erichs.) Zahlbr., Cat. Lich. Univ. 8: 591 (1932),-Buellia myriocarpa f. crassior Erichsen, Das linke Untertraveufer: 151 (1932). Type: Deutschland, Schleswig-Holstein, Lübeck, Dummersdorfer Ufer, Strandblöcke unterhalb Stulperbank. April 1928, Erichsen (HBG!-holotype).

Buellia punctata f. litoralis (Erichsen) Zahlbr., Cat. Lich. Univ. 7: 397 (1931).-Buellia myriocarpa var. litoralis Erichsen, Verh. Bot. Ver. Provinz Brandenburg 72: 48 (1930). Type: Deutschland, Schleswig-Holstein, Insel Alsen, Ostküste bei Kettingholz, an Strandblöcken der supralitoralen Zone, July 1932, Erichsen (HBG!-holotype).

Thallus rimose, whitish to brownish, medulla not amyloid, I- . Apothecia lecideine, $0.3-0.6 \mathrm{~mm}$ diam., broadly sessile, disc plane, margin thin, persistent. Exciple aethalea-type. Hymenium without oil droplets, $70-90 \mu \mathrm{m}$ high, epihymenium brown, hypothecium brown. Ascospores oblong, not constricted at septum, Physconia-type, $10-15 \times 6 \cdot 5-8.5 \mu \mathrm{m}$, ornamentation microrugulate. Conidia filiform, curved, $15-30 \mu \mathrm{m}$ long.

Chemistry: No substances found. 
Taxonomy: Differs from $A$. punctata by the median spore wall thickening, rimose thallus, ecology, and possibly, by the frequent presence of pycnidia. The three collections from the Eastern Alps included here require further critical study.

Ecology and distribution: Mediterranean and Western Europe, North Africa (Morocco). Appears not to occur in Scandinavia. On siliceous rocks and pebbles, mostly near the sea. European specimens have been studied from: Au, $\mathrm{Ga}, \mathrm{Ge}, \mathrm{Br}, \mathrm{Hb}, \mathrm{Hs}$, It, Lu.

\section{Amandinea punctata (Hoffm.) Coppins \& Scheidegger comb. nov.}

Basionym: Verrucaria punctata Hoffm., Deutschlands Flora: 192 (1796) Type: not seen.-B. punctata (Hoffm.) Massal., Ricerch. Auton. Lich.: 81 (1852).

Buellia cupreola Müll. Arg., Mémoir. Soc. Phys. et Hist. Natur. Genève 16: 405 (1862). Type: Erratische Blöcke am Salève, 16 September 1860, f. Müller Arg. (G!-holotype).

? Buellia vagans Müll. Arg., Flora, fena 55: 501 (1872). Type: in thallo et subinde in apotheciis Lecanorae polytropae et $L$. Hageni $b$. umbrinae, nec non juxta thallum in saxi nudi fragmentulis dispersa, f. Müller Arg. (G!--holotype).

Buellia ocellata f. depauperata Anzi ex Arnold, Flora, Jena 53: 215 (1870). Type: Ad murum ex saxis micaceis absque cemento prope Bormium (Piazza): $1200 \mathrm{~m}$ supra mare. (G!-isotype).

Thallus rimose, very thin, greyish. Medulla not amyloid, I-. Apothecia lecideine, $0.2-0.6 \mathrm{~mm}$ diam., broadly sessile or slightly constricted at the base. Disc plane to convex, margin thin, persistent. Exciple aethalea-type. Hymenium without oil droplets, $70 \mu \mathrm{m}$ high, epihymenium brown, hypothecium brown. Ascospores oblong, constricted or not at the septum, Buellia-type, 12-15 $\times 6$ $8 \mu \mathrm{m}$, ornamentation psilate. Pycnidia very rare and inconspicuous. Conidia filiform, curved, up to $15 \mu \mathrm{m}$ long.

\section{Chemistry: No substances found.}

Taxonomy: Saxicolous material, usually placed under this name, is possibly not homogeneous and is not yet completely understood by the author; the relationship between corticolous and saxicolous populations, in particular, needs to be studied. Many of the maritime specimens cited under this name in the literature belong to $A$. lecideina; Mediterranean specimens, often containing stictic and/or norstictic acid, belong to $B$. sequax. Pycnidia in $A$. punctata are usually rare and are difficult to locate, compared to those of other species of Amandinea.

Ecology and distribution: Corticolous, muscicolous and saxicolous. Specimens from all of these substrata have identical conidia. Reported from most parts of Europe as well as from other continents. European specimens have been studied from: $\mathrm{Au}, \mathrm{Ga}, \mathrm{Ge}, \mathrm{He}, \mathrm{Hu}, \mathrm{It}, \mathrm{Lu}, \mathrm{Su}$.

\section{Buellia}

\section{Buellia aethalea (Ach.) Th. Fr.}

Lichenogr. Scand. 1: 604 (1874).-Gyalecta aethalea Ach., Lichenogr. Univ.: 669 (1810). Type: Anglia, Durham, Harriman (UPS-ACH!-isotype). 
Buellia aethaleoides (Nyl.) Oliv., Bull. Acad. Intern. Géogr. Bot. 12: 176 (1903).-Lecidea aethaleoides Nyl., Flora, fena 68: 42 (1885) Type: France, Pyrénées orientales, Amélie, 11 June 1884, Nylander (H-NYL 9280!- holotype).

Rinodina atropallidula (Nyl.) Arnold, Flora, fena 68: 236 (1885)._Lecanora atropallidula Nyl., Flora, fena 55: 428 (1872). Type: France, Pyrénées orientales, Força Réal, alt. $400 \mathrm{~m}$., 16 July 1872, W. Nylander (H-NYL 28570!- holotype).

Lecidea nigerrima Nyl. in Sandst., Abh. naturw. Ver. Bremen 14: 491 (1898) Type: Oldenburg, auf Dachziegeln der beiden Ziegeleien an der Chaussee Zwischenahn-Edewecht, $H$. Sandstede (H-NYL 5795!-isotype?).

Buellia ocellata var. tenella Müll. Arg., Flora, Jena 58: 62 (1875). Type: Switzerland, Valais, Distelgrat, 1874, A. Brun (G!--holotype).

Buellia baltica Erichsen, Verh. Bot. Ver. Prov. Brandenburg 72: 46 (1930). Type: SchleswigHolstein, Kreis Plön, Hohwacht, an eingebetteten Steinen der Gerölldünen bei Strandesberg; supralitorale Zone, 29 August 1933, Erichsen, (HBG!--holotype).

B. sororia Th. Fr., Lichenogr. Scand. 1: 603 (1874). Type: Sweden, Södermanland, Västermo prästgård, 1872, Blomberg (UPS!-lectotype, selected here).

Rinodina ocellulata Bagl. \& Carest., Atti Soc. Crittog. Ital. 2: 210 (1880). Type: Valsesia, Varallo su di un muro a secco fatto con pietre dioritiche, 1877, Carestia [Erb. Critt. Ital. Ser 2: Nr. 721] (MOD!-isotypes).

Buellia sororioides Erichsen, Verhand. Bot. Ver. Prov. Brandenburg 72: 49 (1930). Type: Schleswig-Holstein, Kreis Lauenburg, an erratischen Blöcken bei Buchhorst, 3 October 1926, Erichsen (HBG! - holotype).

Buellia sororioides f. dendritica Erichsen, Verhand. Bot. Ver. Prov. Brandenburg 72: 49 (1930). Type: Schleswig-Holstein, Kreis Flensburg, Angeln. an Geröll am Strande bei Birknach, 21 September 1914, Erichsen (HBG!-holotype).

Buellia subatra Erichsen, Hedwigia 70: 218 (1930). Type: Schleswig-Holstein, Kreis Lauenburg, an einem Blockwall westl. von Kasseburg, am Wege nach Friedrichsruh, in Menge, 1 April 1927, Erichsen (HBG! -holotype).

Thallus areolate, greyish to brownish, often exceeding $1 \mathrm{~cm}$ diam. Medulla amyloid or not. Apothecia cryptolecanorine or zeorine, $0.2-0.4 \mathrm{~mm}$ diam., innate, often immarginate. Exciple aethalea-type. Hymenium without oil droplets, $60-90 \mu \mathrm{m}$ high, epihymenium brown to green, hypothecium colourless to dark brown. Ascospores broadly oblong, slightly constricted at the septum, of Buellia-type, 13-18 $\times 8-10.5 \mu \mathrm{m}$, ornamentation microrugulate. Conidia bacilliform, $5-5 \cdot 5 \mu \mathrm{m}$ long.

Chemistry: Norstictic acid with connorstictic acid; rarely with stictic, cryptostictic, constictic and menegazziaic acids.

Taxonomy: Buellia aethalea is a very variable species with a wide ecological amplitude. Specimens with a non-amyloid medulla, previously named as $B$. sororia, have consistently longer spores than those thalli with an amyloid medulla. Nevertheless, amyloid and non-amyloid specimens are united here under a single taxon, $B$. aethalea, particularly as the amyloid reaction of the medulla has been shown to be very variable even within a single thallus (Scheidegger 1987). The species described under the genus Melanaspicilia are very closely related to $B$. aethalea and are in need of careful revision.

Ecology and distribution: On horizontal to vertical siliceous substrata from the coast to the alpine zone, from the Mediterranean to the subarctic zone. European specimens have been studied from: $\mathrm{Au}, \mathrm{Br}, \mathrm{Bu}, \mathrm{Cz}, \mathrm{Da}, \mathrm{Fe}, \mathrm{Ga}, \mathrm{Ge}$, $\mathrm{Gr}, \mathrm{He}, \mathrm{It}, \mathrm{Ju}, \mathrm{No}, \mathrm{Sa}, \mathrm{Su}, \mathrm{Tu}$. 


\section{Buellia almeriensis Llimona in Vězda}

Lichenes selecti exsiccati Fasc. 48: Nr. 1199 (1973). Type: Spain, Almeria, Cuevas de los Medinas, in collibus gypsaceis, 31 December 1973, Llimona (BCC 600!-holotype).

Buellia heliophila Llimona, Univ. de Barcelona, Fac. de Ciencias: 11 (1974). Type: Spain, Almeria, Canada de Miralles, Llimona (BCC 609!-holotype).

Thallus endolithic to superficial and rimose, medulla not amyloid, I-. Apothecia lecideine, 0.3-0.7 mm diam., sessile, constricted at the base. Disc plane to slightly convex, margin thin, persistent. Exciple leptocline-type, pigment E lacking. Hymenium without oil droplets, c. $95 \mu \mathrm{m}$ high, epihymenium brown, hypothecium dark brown. Ascospores Buellia-type, narrowly oblong, not constricted at septum, $13-18 \times 5.5-6.5 \mu \mathrm{m}$, ornamentation psilate. Conidia bacilliform, $5 \mu \mathrm{m}$ long.

Chemistry: Atranorin, norstictic and connorstictic acids.

Taxonomy: Differs from B. subdisciformis by the thinner exciple, shorter conidia (Fig. 5) and thin-walled spores without median thickening.

Ecology and distribution: On gypsum in semi-desert regions in south-eastern Spain.

\section{Buellia atrocinerella (Nyl.) Scheidegger comb. nov.}

Lecanora atrocinerella Nyl., Flora, fena 55: 428 (1872). Type: France, Pyrénées orientales, ForçaRéal, 16 July 1872, W. Nylander (H-NYL 28564!-holotype).

Thallus rimose to areolate, marginal areolae elongate, brownish grey, matt, medulla not amyloid, I- . Apothecia biatorine, $0 \cdot 2-0.3 \mathrm{~mm}$ diam., innate, with a narrow, brown margin. Exciple aethalea-type. Hymenium without oil droplets, $75 \mu \mathrm{m}$ high, epihymenium brown, hypothecium dark brown. Ascospores oblong, not constricted at the septum, Buellia-type, 10-12 $12-8 \mu \mathrm{m}$, ornamentation psilate. Conidia not found.

Chemistry: Norstictic and connorstictic acids.

Taxonomy: Buellia atrocinerella appears similar to B. tirolensis and differs mainly in the elongate marginal areoles. The author is convinced of the taxonomic status of this taxon by observing adjacent specimens of both species in the field.

Ecology and distribution: On hard siliceous rocks in xerothermic habitats in the Mediterranean region in Europe and North Africa (Morocco). European specimens have been studied from: $\mathrm{Ga}, \mathrm{Hs}, \mathrm{It}, \mathrm{Lu}$.

\section{Buellia badia (Fr.) Massal.}

Memor. Lichenogr. 1853: 124 (1853)._Lecidea badia Fr., Syst. Orb. Veget. 1: 287 (1825). Type: not seen.

Buellia conioptiza (Nyl.) B. de Lesd., Bull. Soc. Bot. France 53: 685 (1907).—Lecidea conioptiza Nyl., Flora, fena 61: 244 (1878). Type: Sur un rocher schisteux près de Châlucet, espèce très rare, 28 July 1877, Lamy (H-NYL 9537a!-holotype). 
Buellia pernigrans (Nyl. in Sandst.) Sandst., Abh. naturw. Verein Bremen 21: 225 (1912).Lecidea pernigrans Nyl. in Sandst., Abh. naturw. Verein Bremen 14: 491 (1898). Type: An einem Granitblock der Glaner Braut, (H-NYL 10394!-isotype).

Buellia schisticola Magnusson, Bot. Not. 108: 306 (1955). Type: Italy, Liguria, Inter Vesima et Arenzano, June 1951, Sbarbaro (UPS!-holotype).

Thallus areolate to squamulose, brown, growing over other lichens, medulla I-, not amyloid. Apothecia lecideine, 0.3-0.7 mm diam., sessile with constricted base, disc plane to slightly convex, margin thin, persistent. Exciple aethalea-type. Hymenium without oil droplets, c. $80 \mu \mathrm{m}$ high, epihymenium brown, hypothecium dark brown. Ascospores broadly oblong, slightly constricted at the septum, Buellia-type, $12-14 \times 7-8 \mu \mathrm{m}$, ornamentation psilate. Conidia not found.

\section{Chemistry: No substances found.}

Taxonomy: In Central and Northern Europe this species has a host range restricted to certain brown and yellow species of Parmelia s. lat. However, in the Mediterranean region B. badia also grows on Acarospora, Aspicilia, Caloplaca, Diploschistes, Rinodina and Umbilicaria and its morphology may vary considerably and seems to be dependent on the thallus of the host. Spores with marked median thickenings, should be compared with Rinodina interjecta (Müll. Arg.) Mayrh., Scheidegger \& Sheard (Mayrhofer et al. 1992).

Ecology and distribution: Buellia badia is a widespread and often common species from lowlands up to alpine regions in Europe, North Africa (Morocco), North America (Egan 1987) and New Zealand (Triebel 1987). European specimens have been studied from: $\mathrm{Au}, \mathrm{Br}, \mathrm{Cz}, \mathrm{Ga}, \mathrm{Ge}, \mathrm{He}, \mathrm{Hs}$, It, $\mathrm{No}, \mathrm{Su}, \mathrm{Tu}$.

\section{Buellia caldesiana Bagl.}

Comm. Soc. Crittogam. Ital. 1(1): 19 (1861). Type: Italy, Liguria, nella valletta di S. Tecla, presso Genova, Baglietto (TO!--isotype).

See also Scheidegger \& Ruef (1988)

Thallus rimose to areolate, chalky, yellowish, medulla faintly amyloid, I+ violet. Apothecia cryptolecanorine or lecideine, $0.4-0.6 \mathrm{~mm}$ diam., innate, immarginate to thinly marginate. Disc plane, slightly whitish-pruinose. Exciple aethalea-type, $40-60 \mu \mathrm{m}$ broad. Hymenium without oil droplets, $58-70 \mu \mathrm{m}$ high, epihymenium olive, hypothecium dark brown. Ascospores oblong, slightly constricted at the septum, Buellia-type, $12.5-14 \times 6.5-7.5 \mu \mathrm{m}$, ornamentation microfoveate. Conidia not observed.

Chemistry: Atranorin and arthothelin.

Taxonomy: This species could be confused with B. epipolia (Ach.) Mong. but differs in the one-septate spores and the presence of xanthones.

Ecology and distribution: Known only from two localities (map in Scheidegger \& Ruef 1988). European specimens have been studied from: Ga, It. 


\section{Buellia concinna Th. Fr.}

Nova Acta Reg. Soc. Scient. Upsal. Ser. 3, 3: 332 (1860). Type: Norway, Finmark, Varanger, Nesseby, 30 August 1857, Th. M. Fries, (UPS!-holotype; BM, GZU, M, O, PC!-isotypes).

See also Scheidegger \& Ruef (1988).

Thallus areolate, yellowish, medulla $\mathrm{I} \pm$ violet, amyloid or not. Apothecia lecideine, $0.5-1 \mathrm{~mm}$ diam., sessile constricted at the base. Disc plane to markedly convex, margin thick, prominent, often disappearing. Exciple dispersa-type, 40-70 $\mu \mathrm{m}$ broad. Hymenium without oil droplets, $60-90 \mu \mathrm{m}$ high, epihymenium brown, hypothecium dark brown. Asci mostly 8- but sometimes 4-spored. Ascospores oblong, often curved, Physconia-type, 13.5$18 \times 7-8 \cdot 5 \mu \mathrm{m}$, ornamentation microrugulate to rugulate. Conidia bacilliform, $4 \cdot 5-5 \cdot 5 \mu \mathrm{m}$ long.

Chemistry: Arthothelin, trichlor- $O$-methyl norlichexanthone.

Taxonomy: Well characterized by the exciple-type and the chemistry.

Ecology and distribution: On hard siliceous rocks, often on perpendicular sites. Widely distributed from the Arctic (Greenland) to Mediterranean mountains. European specimens have been studied from: $\mathrm{Au}, \mathrm{He}, \mathrm{Ga}, \mathrm{Hs}, \mathrm{Fe}$, It, No, Rs, Su.

\section{Buellia dispersa Massal.}

Schedul. Critic. 8: 150 (1856). Type: Nel fossato di Granarolo, 22 January 1853, Baglietto (VER!lectotype, selected here).

B. italica var. tumida Massal., Sched. Critic. 9: 163 (1856).-B. tumida Bagl., Mem. Reale Acad. Sci. Torino, Ser. 2, 17: 423 (1857). Type: Ad saxa micaceo-schistosa Liguriae prope oppidum Voltri (Bosco dell' aqua Santa), Baglietto [Lich. exs. Ital. no. 303] (TO!-isotypes).

Lecidea squamulata Nyl. Flora, Jena 56: 201 (1873), Bull. Soc. Linn. Normandie, Sér. 2, 6: 311 (1873). Type: France, Pyrénées orientales, Collioure, 4 July 1872, Nylander (H-NYL 9229b! holotype).

Lecidea dispersa var. subeffigurans Nyl. in Lamy, Bull. Soc. Bot. Fr. 30: 421 (1883). Type: France, sur du schiste à Lourdes, E. Lamy (H-NYL 9228! —isotype).

Buellia tergestina Steiner et Zahlbr. in Zahlbr., Annal. Naturhist. Hofmus. Wien 9: 134 (1894). Type: Litorale austriacum, ad saxa arenaria in agro tergestina, Schuler [Krypt. Exs. Vindob. no. 58] (GZU, W!-isotypes).

Buellia duartei Samp., Liquen. Ined.: 1 (1920). Type: Portugal, Povoa de Lanhoso, 29 September 1919, Sampaio (W!-isotype).

Buellia subsquamosa sensu Buschardt (1979), non Steiner (1907).

Thallus rimose, areolate to squamulose, often slightly placodioid, whitish to ochre, medulla not amyloid, I - . Apothecia lecideine, 0.4-0.7 mm diam., sessile with constricted base, disc plane to convex. Exciple dispersa-type. Hymenium without oil droplets, $70 \mu \mathrm{m}$ high, epihymenium brown, hypothecium dark brown. Ascospores of Physconia-type, narrowly oblong, 12-14 $\times 6.5-8 \mu \mathrm{m}$, ornamentation microrugulate. Conidia bacilliform, 5-6 $\mu \mathrm{m}$ long.

Chemistry: Atranorin, chloratranorin, 2'-O-methylperlatolic acid. 
Taxonomy: Buellia dispersa is clearly defined in most regions by its distinctive chemistry and exciple type. Only a population in Valais (Switzerland) lacks confluentic and $2^{\prime}-O$-methylperlatolic acids. This population differs from $B$. excelsa in lacking oil droplets in the hymenium. The ecology of the Valais material is similar to that known from other inner alpine dry valleys, which have the typical chemistry of $B$. dispersa.

Ecology and distribution: Widely distributed in the Mediterranean region and the inner alpine dry valleys (map in Scheidegger 1991). On siliceous or slightly calcareous rocks in xerothermic localities. European specimens have been studied from: Ga, Gr, He, Hs, Hs, It, Ju, Lu, Sa, Si, Tu.

\section{Buellia ectolechioides (Vain.) Erichsen}

Verhandl. Bot. Ver. Prov. Brandenburg 72: 45 (1930).-Melanaspicilia ectolechioides Vainio, Arkiv för Botan. 8(4): 77 (1909). Type: Siberia, ad lapidem graniticum in regione meridiem versus a pago Pitlekai sita, Almquist (TUR-holotype).

Prothallus usually well-developed, black, often fimbriate. Thallus granular, consisting of a single or a few, scattered areoles, whitish to greyish, medulla amyloid or not, $\mathrm{I} \pm$. Apothecia cryptolecanorine to zeorine, $0 \cdot 3-0.4 \mathrm{~mm}$ diam., immersed. Exciple aethalea-type. Hymenium without oil droplets, $60-80 \mu \mathrm{m}$ high, epihymenium brown to green, hypothecium colourless to dark brown. Ascospores of Buellia-type, 13-18 $\times 7-10 \mu \mathrm{m}$, oblong, slightly constricted at the septum, ornamentation microrugulate. Conidia not found.

\section{Chemistry: Norstictic acid.}

Taxonomy: Buellia ectolechiodes belongs to the B. aethalea complex and is distinguished by the small thalli consisting of scattered areoles. This species is abundant in the arctic and subarctic regions. Although the morphology and ecology are relatively uniform for $B$. ectolechioides and differ considerably from $B$. aethalea, the author is not certain about the taxonomic status of $B$. ectolechioides. As Hafellner (1979) stated, B. leptolepis Bagl. \& Carestia is probably related to $B$. ectolechioides. Because the type material of $B$. leptolepis is not available (Hafellner 1979) and because the delimitation of the species has to be done in a revision of the Asian taxa, I use the well known name $B$. ectolechioides for this species, although, if conspecific, $B$. leptolepis would be the valid name.

Ecology and distribution: Arctic to subarctic, a few specimens from the Alps probably belong here. European specimens have been studied from: No, Su.

\section{Buellia excelsa (Leighton) A.L. Smith}

Monogr. Brit. Lich. 2: 174 (1911).-Lecidea excelsa Leighton, Grevillea 4: 78 (1876).-Buellia punctata var. excelsa (Leighton) Sheard, Lichenologist 2: 245 (1964). Type: Ireland, Galway. Connemara, on the summit of Mt. Doughruagh, June 1875, Larbalestier (BM!-lectotype).

Thallus rimose to areolate, whitish to ochre, medulla not amyloid, I-. Apothecia lecideine, $0.3-0.6 \mathrm{~mm}$ diam., narrowly marginate, disc slightly 
convex to hemispherical. Exciple dispersa-type. Hymenium with oil droplets, $60 \mu \mathrm{m}$ high, epihymenium brown, hypothecium dark brown. Ascospores Physconia-type, oblong, $11.5-15 \times 5-8 \mu \mathrm{m}$, ornamentation microrugulate. Conidia not observed.

Chemistry: Atranorin, chloratranorin.

Taxonomy: The species superficially resembles Hafellia leptoclinoides and $B$. subdisciformis but differs in exciple type and chemistry.

Ecology and distribution: Buellia excelsa is rarely recorded and occurs on granite pebbles and boulders in dunes and in mountains. European specimens have been studied from: $\mathrm{Br}, \mathrm{Da}, \mathrm{Hb}, \mathrm{Sa}$.

\section{Buellia fimbriata (Tuck.) Sheard}

Bryologist 72: 221 (1969).-Rinodina radiata b. fimbriata Tuck., Synops. North Americ. Lichens 1: 205 (1882). Type: Cliffs at the Mission Dolores, California, Bolander 166 (FH-Tuck!-lectotype).

Buellia cerussata Llimona \& Werner, Acta Phytotax. Barc. 16: 18 (1975). Type: Crescit ad saxa vulcanico-andesitica in Hispaniae Gata montibus, prope Almeria urbem, loco El Monsul, ad alt. 20 m., 30 November 1970, X. Llimona (BCC!-holotype).

Prothallus black, fimbriate, thallus areolate, whitish to bluish, medulla not amyloid, I- . Apothecia cryptolecanorine, $0.3-0.5 \mathrm{~mm}$ diam., disc plane to hemispherical, often slightly pruinose. Exciple aethalea-type. Hymenium without oil droplets, $c .60 \mu \mathrm{m}$ high, epihymenium brown, hypothecium dark brown. Ascospores broadly oblong, not constricted at septum, Buellia-type, 9-15 $\times 5 \cdot 5-7 \mu \mathrm{m}$, ornamentation rugulate. Conidia bacilliform, $6 \cdot 5-11 \mu \mathrm{m}$ long.

Chemistry: 3-Chlorodivaricatic acid.

Taxonomy: This species is characterized by its fimbriate prothallus, unique chemistry and spore ornamentation. Dimelaena radiata shares the same habitat with $B$. fimbriata in southeastern Spain and also has the same thallus colour and the same chemistry. Dimelaena radiata differs from $B$. fimbriata by its placodioid thallus, the lack of a prothallus and its plane, not convex, disc.

Ecology and distribution: On porous rocks in xerothermic localities in the thermomediterranean belt (map in Scheidegger 1991). European specimens have been studied from: $\mathrm{Ga}, \mathrm{Gr}, \mathrm{Hs}$, It, Sa.

\section{Buellia fusca (Anzi) Kernst.}

Zeitschr. Ferdinandeums 35: 306 (1893).-Buellia spuria var. fusca Anzi, Catal. Lich. Sondr.: 87 (1860). Type: Ad rupes silaceas prope Novum Comum (S. Martino), Anzi [Lich. Lang. no. 195] (BERN!, UPS!, W!-isotypes).

Thallus areolate, brown to ochre, often glossy, medulla not amyloid, I- . Apothecia biatorine, $0 \cdot 15-0.3 \mathrm{~mm}$ diam., innate. Exciple aethalea-type. Hymenium without oil droplets, $60 \mu \mathrm{m}$ high, epihymenium brown, hypothecium dark brown. Ascospores broadly oblong, not constricted at the septum, Buelliatype, $10-12 \times 5-6 \mu \mathrm{m}$, ornamentation psilate. Conidia not observed. 
Chemistry: 2'-O-Methylperlatolic acid.

Taxonomy: Buellia fusca resembles $B$. tirolensis, from which it mainly differs in chemistry, larger thalli and marginate apothecia.

Ecology and distribution: The species is rarely recorded and is only known from the southern Alps and the eastern Pyrénées (Scheidegger 1991). It grows in shady places on overhanging or vertical sides of boulders near soil level in Mediterranean scrub vegetation. European specimens have been studied from: It, Ga, Hs.

\section{Buellia griseosquamulata Scheidegger sp. nov.}

Thallus squamulosus ad areolatus, griseus. Medulla non amyloidea. Apothecia lecideina, sporae 9.5-11 $\mu \mathrm{m}$ longae 5-9 $\mu \mathrm{m}$ crassae, typo 'Physconia'. Differt a Rinodina interjecta praecipue sporis minoribus et thallo griseo.

Typus: Italy, Sardinia, Sassari, Capo d'Orso east of Palau, 60-109 m, high granitic boulders, 6 May 1986, F. Poelt (GZU!-holotypus et isotypus).

Thallus areolate to squamulose, greyish, medulla not amyloid, I-. On Buellia tirolensis. Apothecia lecideine, $0.3-0.5 \mathrm{~mm}$ diam., sessile with broad base, disc plane, margin thin, prominent. Exciple $18-25 \mu \mathrm{m}$ broad, aethaleatype. Hymenium c. $55 \mu \mathrm{m}$ high, without oil droplets, epihymenium brown, hypothecium dark brown, c. $100 \mu \mathrm{m}$ high. Ascospores broadly oblong, 9.5-11 $\mathrm{x}$ 5-9 $\mu \mathrm{m}$, Physconia-type, not constricted at the septum (Fig. 8b), ornamentation psilate. Conidia not observed.

\section{Chemistry: No substances detected.}

Taxonomy: Buellia griseosquamulata differs from other species of Buellia by the squamulose thallus, the short spores and the absence of lichen substances. Rinodina interjecta (Müll. Arg.) Mayrh. \& Scheidegger differs from $B$. griseosquamulata by its areolate, brown thallus, the presence of crystalline lichen substances in the medulla, and the longer spores.

\section{Buellia imshaugii Hafellner}

Nova Hedwigia, Beih. 62: 58 (1979). Type: Canada, South Saskatchevan, 13 July 1879, f. Macoun (as Buellia lepidastra Tuck.) (CANL 19326!-holotype).

Thallus areolate, greyish brown, medulla not amyloid, I-, an obligate parasite on Dimelaena oreina. Apothecia lecideine, 0.2-0.7 mm diam., sessile with a constricted base, disc convex. Exciple dispersa-type. Hymenium without oil droplets, $90 \mu \mathrm{m}$ high, epihymenium brown, hypothecium dark brown. Ascospores, Buellia-type, $12-16 \times 6.5-7.5 \mu \mathrm{m}$, ornamentation microrugulate. Conidia bacilliform, $6-9 \mu \mathrm{m}$ long.

Chemistry: No substances found.

Taxonomy: European specimens consist of very small thalli (up to $1 \mathrm{~cm}$ ); the identity with the type is tentative. TLC of $B$. imshaugii revealed the presence of usnic and stictic acids; both substances are also present in the host lichen. 
Because the chemistry of the host is frequently also detectable in its parasite, we are still not sure about the actual chemistry of $B$. imshaugii.

Ecology and distribution: Known only from the type collection and a few fragmentary collections from the Mediterranean region where it grows in xerothermic sites. European specimens have been studied from: Hs, Sa.

\section{Buellia indissimilis (Nyl.) B. de Lesd.}

Lich. Mexique: 26 (1914)._Lecidea indissimilis Nyl., Flora, fena 64: 181 (1881). Type: Portugal, Porto, 1880, Newton (H-NYL 9310!-lectotype; H-NYL 10658!-isotype).

See also Scheidegger \& Ruef (1988).

Thallus rimose to areolate, yellowish, medulla amyloid, I + violet. Apothecia biatorine, $0 \cdot 4-0.5 \mathrm{~mm}$ diam., immersed to broadly sessile, disc plane. Exciple aethalea-type. Hymenium without oil droplets, c. $58 \mu \mathrm{m}$ high, epihymenium brown, hypothecium light brown. Ascospores oblong, not constricted at septum, Buellia-type, $10-12 \times 6-9 \mu \mathrm{m}$, ornamentation psilate. Conidia bacilliform, $6 \mu \mathrm{m}$ long.

Chemistry: Norstictic acid, dichlorlichexanthone.

Taxonomy: Well characterized by its chemistry. Resembles small forms of thin B. spuria or B. stellulata but differs in the chemistry and colour of the epihymenium.

Ecology and distribution: Known only from the type collection in Portugal.

\section{Buellia jugorum (Arnold) Arnold}

Flora, fena 67: 588 (1884).-Buellia verruculosa var. jugorum Arnold, Verh. zool. bot. Ges. Wien 28: 295 (1879). Type: Austria, Tyrolia, an Glimmergesteinen der Einsattlung der Bergschneide östlich ober den Plendele Seen, Kühthei, 2600 m, 8 August 1877, Arnold (M!-lectotype, M, PC! W!isotypes).

See also Poelt (1960) and Scheidegger \& Ruef (1988).

Thallus areolate, slightly placodioid, up to $1.8 \mathrm{~mm}$ long, yellow, medulla not amyloid, I - . Apothecia cryptolecanorine to lecideine, 0.3-0.6 mm diam., innate to broadly sessile with a black, narrow margin. Exciple aethaleatype. Hymenium without oil droplets, 50-70 $\mu \mathrm{m}$ high, green in lower part, epihymenium brown, hypothecium dark brown. Ascospores oblong, slightly constricted at the septum, Buellia-type, 11-15 $\times 6-8.5 \mu \mathrm{m}$, ornamentation microrugulate. Conidia bacilliform, 6-9 $\mu \mathrm{m}$ long.

\section{Chemistry: Arthothelin.}

Taxonomy: Closely related to $B$. ocellata, from which it differs in having longer conidia (Fig. 5) and considerably more elongate marginal areoles. The relationship of the Siberian specimens to $B$. jugorum is at present unclear. 
Ecology and distribution: On small pebbles in very windy localities in the alpine zone of the Alps, the Pyrénées and Scandinavia. European specimens have been studied from: $\mathrm{Au}, \mathrm{Ga}, \mathrm{He}, \mathrm{It}, \mathrm{No}, \mathrm{Rs}, \mathrm{Sa}, \mathrm{Su}$.

\section{Buellia leptocline (Flotow) Körber}

Syst. Lich. German.: 255 (1855).-Lecidea leptocline Flotow, Botan. Zeitung 8: 555 (1850). Type: Seifersdorf bei Hirschberg, Grünstein. 24 April 1841, Flotow (UPS!-neotype, selected here).

Buellia hypopodioides (Nyl.) Arnold, Flora, fena 53: 479 (1871).-Lecidea hypopodioides Nyl., Flora, fena 50: 372 (1867). Type: Tavastia australis, Evois, 1866, f.P. Norrlin (H-NYL 10478!, UPS!-isotypes).

Buellia gevrensis Th. Fr., Lichenogr. Scandin. I: 598 (1874). Type: Norvegia, Finmark, Mortensnaes, Storfjeldet, 20 August $1864, T h$. M. Fries (UPS!-holotype).

Lecidea hypopodioides f. ferruginascens Nyl., Flora, fena 60: 463 (1877). Type: Fennia, Lapponia inarensis, Enare, Pitkävuono. September 1870, F. Silén (H-NYL 10468!--isotype).

Thallus chasmolithic to rimose, whitish, medulla strongly amyloid, I+ violet. Apothecia lecideine, 0.5-1.2 mm diam., sessile with constricted base, disc plane to convex, margin thick and prominent. Exciple leptocline-type. Hymenium without oil droplets, c. $75 \mu \mathrm{m}$ high, epihymenium brown, hypothecium dark brown. Ascospores oblong, not constricted at the septum, Physconia-type, $12-16 \times 7.5-8.5 \mu \mathrm{m}$, ornamentation rugulate, rarely psilate. Conidia bacilliform, $4-5 \mu \mathrm{m}$ long.

Chemistry: Atranorin.

Taxonomy: Characterized by its exciple-type, chemistry and ecology. A well-defined species not easily confused with other related taxa.

Ecology and distribution: On perpendicular and overhanging, rain-exposed parts of siliceous boulders in subalpine to alpine regions in Central and Northern Europe. European specimens have been studied from: $\mathrm{Au}, \mathrm{Be}, \mathrm{Br}$, $\mathrm{Cz}, \mathrm{Fe}, \mathrm{Ga}, \mathrm{Ge}, \mathrm{He}$, It, No, Po, Su.

\section{Buellia longispora Scheidegger sp. nov.}

Thallus granulosus ad bullatus, albidus, nitidus. Medulla intense vel laeviter I + coerulescens. Apothecia lecideina, sessilia, discis margine lata. Excipulum type 'dispersa'. Sporae 15-30 $\mu \mathrm{m}$ longae $7-10 \mu \mathrm{m}$ crassae aetate 3 -septatae. Differt a Buellia dispersa praecipue sporis majoribus ornamento rugulato et thallo acidum sticticum continenti.

Typus: Italy, Sardinia, Prov. Nuoro. Barbagia Seulo, road Seui-Lanusei. M. Arcueri, close to cantoniera Arcueri, $9^{\circ} 21^{\prime} \mathrm{E}, 39^{\circ} 49^{\prime} \mathrm{N}, 950 \mathrm{~m}$ alt, N. exponierte Vertikalflächen einer $10 \mathrm{~m}$ hohen Felsrippe, Scheidegger-10420 (BERN!-holotypus).

Prothallus black, thallus granular to bullate, whitish, medulla strongly amyloid, I+ violet. Grows over other crustose lichens such as Aspicilia sp. Apothecia lecideine, 0.5-1 mm diam., sessile with constricted base, disc plane to hemispherical. Exciple dispersa-type. Hymenium without oil droplets, c. $85 \mu \mathrm{m}$ high, epihymenium brown, hypothecium dark brown. Ascospores narrowly oblong, not constricted at the septum, 1-3 septate, Buellia-type, 15$30 \times 7-10 \mu \mathrm{m}$, ornamentation rugulate (Fig. $8 \mathrm{~A}$ ). Conidia bacilliform, 5.5-7 $\mu \mathrm{m}$ long. 
Chemistry: Atranorin, norstictic acid with connorstictic acid, stictic acid with cryptostictic, constictic and menegazziaic acids.

Taxonomy: Buellia longispora is related by exciple type to $B$. dispersa, from which it differs in its longer spores and the presence of stictic and/or norstictic acid instead of 2' $O$-methylperlatolic acid.

Ecology and distribution: Rare on granite boulders in the Mediterranean region. European specimens have been studied from: $\mathrm{Ga}, \mathrm{Hs}$, It.

Selected specimens investigated: Italy: Sardinia, Prov. Nuoro. Gennargentu Mts. Arcu Correboi: M. Arbu, on siliceous rocks, $40^{\circ} 04^{\prime} \mathrm{N}, 9^{\circ} 21^{\prime} \mathrm{E}, 17 \mathrm{July} 1987, C$. Scheidegger (hb Scheidegger). France: Basses-Alpes, Versant ouest du Rocher (1050 m.s.m.) de Méolans. Grès silicieux et calcaires du Flysch décalcifiés en surface, 10 August 1951, Clauzade (MARSJ).

\section{Buellia miriquidica Scheidegger}

Bot. Helv. 97: 112 (1987). Type: Germany, Baden-Württemberg, Urberg-Schwand bei St. Blasien, Auf Porphyr, lichtreicher Standort, $930 \mathrm{~m}, 15$ June 1969, Wirth (Wirth 1665! - holotype).

Thallus areolate, grey, medulla amyloid, I+ violet. Apothecia cryptolecanorine to lecideine, $0 \cdot 25-0 \cdot 8 \mathrm{~mm}$ diam., innate to sessile, disc plane to convex. Exciple aethalea-type. Hymenium without oil droplets, 40-68 $\mu \mathrm{m}$ high, epihymenium brown to olive, hypothecium brown. Ascospores broadly oblong, markedly constricted at the septum, Buellia-type, $6-8 \times 3.5-5 \mu \mathrm{m}$, ornamentation psilate. Conidia bacilliform, 3.5-4 $\mu \mathrm{m}$ long.

Chemistry: Miriquidic acid.

Taxonomy: Related to $B$. uberior, but distinguished by the psilate spore ornamentation and chemistry.

Ecology and distribution: On vertical faces of hard granitic rocks in the alpine and arctic zone in Central and Northern Europe (map in Scheidegger 1987) and in Greenland. European specimens have been studied from: $\mathrm{Au}, \mathrm{Ga}, \mathrm{Ge}, \mathrm{He}$, It, No, Su.

\section{Buellia ocellata (Flotow) Körber}

Syst. Lich. German.: 224 (1855).

See also Scheidegger \& Ruef (1988).

Thallus areolate, yellowish, medulla not amyloid, I- . Apothecia cryptolecanorine, $0 \cdot 2-0.5 \mathrm{~mm}$ diam., disc plane. Exciple aethalea-type. Hymenium without oil droplets, lower part with pigment A, 60-95 $\mu \mathrm{m}$ high epihymenium brown, hypothecium dark brown. Ascospores Buellia-type, oblong, slightly constricted at the septum, $13-15 \times 6 \cdot 5-8.5 \mu \mathrm{m}$, ornamentation microrugulate. Conidia bacilliform, $4 \cdot 5-5 \cdot 5 \mu \mathrm{m}$ long.

Chemistry: Arthothelin, stictic acid in a few populations.

Taxonomy: Differs from other species of the $B$. aethalea group by the presence of xanthones. For comparison with $B$.jugorum see under that species. 
Ecology and distribution: On siliceous rocks from sea level to the subalpine zone in the Mediterranean and Central European region (map in Scheidegger \& Ruef 1988). European specimens have been studied from: Au, Br, $\mathrm{Da}, \mathrm{Ga}, \mathrm{Ge}$, $\mathrm{Gr}, \mathrm{Hb}, \mathrm{He}$, It, Ju, Po, Rm, Rs, Sa, Si, Su.

\section{Buellia parvula (Mayrh. \& Poelt) Mayrh. \& Scheidegger comb. nov.}

Rinodina parvula Mayrhofer \& Poelt, Bibl. Lich. 12: 138 (1979). Type: Yugoslavia, Makedonia, Sar planina, Rudoka, Popova sapka W Tetovo, Hänge W der Bergstation der Bergbahn, $\pm 2000 \mathrm{~m}$ alt, 8 July 1977 , Poelt (GZU!-holotype).

Thallus consisting of a few, thick, greyish areoles. Medulla not amyloid, I- . Apothecia cryptolecanorine to lecanorine, 0.2-0.6 mm diam., disc plane. Exciple aethalea-type. Hymenium without oil droplets, $90 \mu \mathrm{m}$ high, epihymenium brown, hypothecium hyaline. Ascospores Buellia-type, 13-19 $\times 8-11.5 \mu \mathrm{m}$, ornamentation microrugulate. Conidia not observed.

\section{Chemistry: No substances detected by TLC.}

Taxonomy: Related to B. aethalea but often with lecanorine apothecium and lacking norstictic acid.

Ecology and distribution: A rare species on slightly calcareous rocks in the alpine region of European mountains (Mayrhofer \& Poelt 1979). European specimens have been studied from: $\mathrm{Au}, \mathrm{He}, \mathrm{Ju}$.

\section{Buellia sardiniensis Steiner}

Verh. zool. bot. Ges. Wien 57: 348 (1907). Type: circa Orri in Sard. merid. exempl. dextrum (W!holotype).

B. lusitanica Steiner, Verh. zool. bot. Ges. Wien 57: 347 (1907). Type: Portugal, 1866, v. Solms (H-NYL 10467c!-holotype).

Thallus often $>5 \mathrm{~cm}$ diam, thin to thick, rimose to areolate or bullate, white, medulla amyloid, I + violet. Apothecia lecideine, $0.4-0.8 \mathrm{~mm}$ diam., sessile, with constricted base, disc plane to convex, margin thick, prominent. Exciple leptocline-type. Hymenium without oil droplets, epihymenium brown, about $80 \mu \mathrm{m}$ high, hypothecium dark reddish brown. Ascospores oblong, constricted at septum, Physconia-type, 13-15 $\times 6-7 \mu \mathrm{m}$, ornamentation microrugulate. Conidia bacilliform, $6 \cdot 5-8 \mu \mathrm{m}$ long.

Chemistry: Atranorin, gyrophoric, norstictic and connorstictic acids.

Taxonomy: When on maritime rocks, $B$. sardiniensis may occur with $B$. subdisciformis, however chemistry and amyloid reaction of the medulla are constant even in this situation. For distinction from B. saxorum see below.

Ecology and distribution: On horizontal to vertical, sun-exposed surface on hard granitic rocks on maritime and inland habitats in the Mediterranean region (map in Scheidegger 1991), including North Africa (Libya, Morocco, Tunisia). European specimens have been studied from: Ga, Hs, It, Lu, Sa. 


\section{Buellia saxorum Massal.}

Ricerch. Auton. Lich.: 82 (1852). Type: Colli euganei, S. Daniele (VER!-?holotype).

B. superans (Nyl.) Mong., Bull. Acad. Intern. Géogr. Bot. 9: 207 (1900)._Lecidea superans Nyl., Bull. Soc. Linn. Normand., Sér. II, 6: 292 (1873). Type: Ad saxa schistosa in La Massane, frequens, Nylander (H-NYL 10610! - holotype).

Thallus often $>5 \mathrm{~cm}$ diam., thin, rimose to areolate, white, medulla amyloid, I + violet. Apothecia lecideine, 0.4-0.8 mm diam., sessile with constricted base, disc plane to convex, margin thick, prominent. Exciple leptocline-type. Hymenium without oil droplets, c. $80 \mu \mathrm{m}$ high, epihymenium brown, hypothecium dark reddish brown. Spores Physconia-type, oblong, constricted at septum, $12-14 \times 6-7.5 \mu \mathrm{m}$, ornamentation microrugulate. Conidia bacilliform, $4 \cdot 5-7 \cdot 5 \mu \mathrm{m}$ long.

Chemistry: Atranorin, gyrophoric and lecanoric (trace) acids.

Taxonomy: Differs from $B$. sardiniensis in lacking norstictic acid and probably in its ecology. Possibly $B$. sardiniensis is only a chemical strain of $B$. saxorum. Until more is known about the geographical distribution and variation of $B$. saxorum and $B$. sardiniensis it is better to regard the two taxa as separate species.

Ecology and distribution: On \pm vertical surfaces of hard siliceous rocks: (map in Scheidegger 1991). European specimens have been studied from: Br, Ga, Hs, It.

\section{Buellia sequax (Nyl.) Zahlbr.}

Cat. Lich., Univ. 7: 410 (1931)._Lecidea sequax Nyl., Flora, fena 58: 302 (1875). Type: Quartz sur les coteaux de la Vienne près du moulin de l'Aiguille, 11 January 1872, Lamy (H-NYL 9538!lectotype, selected here, H-NYL 9539!-isotype).

Buellia heteropsis Müll. Arg., Bull. Soc. Murithienne du Valais 10: 57 (1881). Type: Blöcke an den Wänden nordwestl. der Rhonebrücke b. Brig, 15 September 1880, J. Müller Arg. (G!-holotype).

B. abstracta (Nyl.) Oliv., Bull. Acad. Intern. Géogr. Bot. 12: 176(1903).-Lecidea abstracta Nyl., Flora, fena 66: 102 (1883). Type: France, Pyrénées, Cauterets, E. Lamy (H-NYL 9740!-holotype, $\mathrm{M}$ !-isotype).

B. caloplacivora Llimona \& Egea, Butll. Inst. Cat. Hist. Nat. 51: (Sect. Bot. 5): 81 (1984). Type: Spain, Islas Columbretes, Columbrete Grande, $20 \mathrm{~m}$ alt, cerca del embarcadero. 4 May 1973, $X$. Llimona (BCC! - holotype, -isotypes).

B. meiosperma auct., non (Nyl.) Müll. Arg., Revue Mycol. 9: 86 (1887), Nyl., Annal. Scienc. Nat. Bot. Sér. 4, 15: 49 (1861).

Thallus chasmolithic to epilithic, granular to areolate, greyish, medulla not amyloid, I - , thallus often growing over crustose lichens. Apothecia lecideine or cryptolecanorine, $0.3-0.7 \mathrm{~mm}$ diam., innate to sessile, disc plane to markedly convex, often slightly pruinose, margin thin, persistent. Exciple aethaleatype. Hymenium without oil droplets, c. $65 \mu \mathrm{m}$ high, epihymenium brown, hypothecium dark brown. Ascospores oblong, slightly constricted at septum, Buellia-type, $11-13.5 \times 4.5-5.5 \mu \mathrm{m}$, ornamentation faintly microrugulate. Conidia not observed.

Chemistry: No substances found, or with norstictic and connorstictic acids. 
Taxonomy: Buellia sequax is a polymorphic species. The type of $B$. abstracta combines a chasomolithic thallus and narrow spores and was thus previously thought to be a good species. Similar specimens are regularly found on schists in the Mediterranean and sub-Mediterranean area (Scheidegger 1987). Subsequently numerous intermediate forms with granular to areolate thalli, with or without norstictic acid, have been found. Buellia sequax therefore circumscribes a polymorphic species that cannot be satisfactorily subdivided at the moment into more uniform elements.

Ecology and distribution: Often growing over crustose lichens on maritime rocks, mainly of sandstone, but also found on schists and small siliceous pebbles in open scrub vegetation from the coast to about $1200 \mathrm{~m}$ from the Mediterranean region to the Channel Islands. European specimens have been studied from: $\mathrm{Au}, \mathrm{Br}, \mathrm{He}, \mathrm{Ga}, \mathrm{Hs}$, It, $\mathrm{Lu}$.

\section{Buellia spuria (Schaerer) Anzi}

Cat. Lich. Sondr.: 87 (1860).-Lecidea spuria Schaerer, Lich. Helvet. Spicil. Sect. 3: 127 (1828). Type: Ad saxa granitica, Schleicher 1823 sub Lecidea atro-alba; Hepp, Flechten Europas Nr. 33, an Alpenfindlingen, Zürich, Hepp (BERN!-neotype, selected here).

B. lactea (Massal.) Körber, Parerg. Lich.: 183 (1860).-Catolechia lactea Massal. Ricerch. Auton. Lich.: 84 (1852).-Buellia italica var. lactea Massal., Schedul. Critic. 9: 163 (1856). Type: Monte Bolca, ad basaltica, 1849, Massalongo (MOD!-holotype).

Buellia olivaceofusca (Anzi) Zahlbr., Cat. Lich. Univ. 7: 385 (1931).-Buellia lactea var. olivaceofusca Anzi, Atti Soc. Ital. Sci. Natur. 9: 252(1866). Type: Sul micaschisto nel monte Pisano (TO!-holotype, W! - isotype).

B. italica var. recobarina Massal., Sched. Critic. 9: 163 (1856). Type: Vive sulle rupi nelle vicinanze di Voltri, (W!-isotype).

Buellia italica var. insularis Bagl., Nuov. Giorn. Bot. Ital. 3: 264 (1871). Type: Sardinia, Orri, Baglietto (G!-isotype).

Thallus rimose to areolate, thin to more than $1 \mathrm{~mm}$ thick, greyish to whitish, medulla amyloid, I+ violet. Apothecia cryptolecanorine or lecideine, 0.2$0.7 \mathrm{~mm}$ diam., with narrow, prominent margin, innate to broadly sessile. Exciple aethalea-type. Hymenium without oil droplets, c. $80 \mu \mathrm{m}$ high, epihymenium green to olive, hypothecium dark brown. Ascospores oblong, not constricted at the septum, Buellia-type, 9-15 $\times 5 \cdot 5-7 \mu \mathrm{m}$, ornamentation psilate to microrugulate. Conidia bacilliform, 4.5-6 $\mu \mathrm{m}$ long.

Chemistry: Atranorin, chloratranorin, norstictic acid with connorstictic acid, stictic acid with cryptostictic, constictic and menegazziaic acids.

Taxonomy: Thin thalli of B. spuria could be mistaken for B. stellulata from which they may be distinguished by their amyloid, I+ violet, medulla and different chemistry. In the protologue of Lecidea spuria Schaerer indicates as type specimen 'Lecidea atro-alba Schleicher 1823'. Unfortunately, the major part of the lichenological collection of Schleicher in LAUS is very badly curated. Most specimens are loosely packed in open trays, which have been inverted in disintegrating boxes. One box labelled as Lecidea atro-alba contained two specimens on different substrata; neither of the two samples agrees 
with the protologue and it is therefore highly probably that the label and specimens do not correspond and that the type material of $B$. spuria is irretrievably confused. For this reason the neotype cited above has been selected.

Ecology and distribution: Widely distributed in the Mediterranean area, rare in Central Europe, mostly on slightly inclined faces of low granitic boulders (map of chemotype with norstictic acid only is given in Scheidegger 1991). European specimens have been studied from: $\mathrm{Br}, \mathrm{Ga}, \mathrm{Ge}, \mathrm{He}, \mathrm{Hi}, \mathrm{It}, \mathrm{Ju}, \mathrm{Lu}$, $\mathrm{Rm}, \mathrm{Sa}, \mathrm{Tu}$.

\section{Buellia stellulata (Tayl. in Mack.) Mudd}

Manual Brit. Lich.: 216 (1861).-Lecidea stellulata Tayl. in Mack., Flora Hibernica 2: 118 (1836). Type: Carig Mountain, Taylor (BM!-holotype).

B. maritima (Massal.) Bagl. in Massal., Schedul. Critic. 8: 150 (1856).-Catolechia maritima Massal., Framm. Lich.: 22 (1855). Type: Ad saxa in Liguria prope Genuam [Lich. exs. Ital. no. 271. part of this number is confused with no. 272, B. dispersa] (TO!-isotype).

Buellia subalbula var. adriatica Zahlbr., Oesterr. Bot. Zeitschr. 53: 333 (1903). Type: Insel Pelagosa piccola, an Kalkfelsen, Ginzberger (W!-holotype).

B. candidula Arnold, Verh. zool.bot. Ges. Wien 22: 291 (1872). Type: An Blöcken oberhalb Gries, Arnold (M!-holotype).

Lecidea microtera Nyl., Flora, Jena 56: 202 (1873), Bull. Soc. Linn. Normandie Sér. 2, 6: 311 (1873). Type: Pyrénées, ad saxa in vinea Naudini, W. Nylander (H-NYL 9213! - holotype).

Buellia stellulata var. candidella (Nyl.) Boist., Nouv. Flore Lich. 2: 237 (1903).-Lecidea candidella Nyl., Flora, Jena 65: 457 (1882), nomen nov. pro Lecidea candidula Nyl., Flora, fena 64: 180 (1881). Type: France, Pyrénées Centrales. In monte Cazaril prope Luchon, 1853, Nylander (H-NYL 9215!-holotype).

Thallus often less than $1 \mathrm{~cm}$ diam., rimose, whitish, medulla not amyloid, $\mathrm{I}-$. Apothecia cryptolecanorine to lecideine, $0.15-0.3 \mathrm{~mm}$ diam., innate. Exciple aethalea-type. Hymenium without oil droplets, 45-70 $\mu \mathrm{m}$ high, epihymenium green to olive, hypothecium dark brown. Ascospores oblong, not constricted at the septum, Buellia-type, $10-13 \times 5-6 \mu \mathrm{m}$, ornamentation rugulate or psilate. Conidia bacilliform, 3.5-4 $\mu \mathrm{m}$ long.

Chemistry: Atranorin, confluentic, $2^{\prime}-O$-methylperlatolic acids.

Taxonomy: Specimens on limestone often have a thicker thallus than those on siliceous substrata. Because other characters, such as apothecial margin, are not correlated with thallus thickness, $B$. candidula is considered here as a synonym of $B$. stellulata.

Ecology and distribution: On sun-exposed, calcareous or siliceous rocks in southern and central Europe. European specimens have been studied from: Au, $\mathrm{Br}, \mathrm{Co}, \mathrm{Da}, \mathrm{Ga}, \mathrm{Ge}, \mathrm{Hb}, \mathrm{He}, \mathrm{Hs}, \mathrm{Hu}, \mathrm{It}, \mathrm{Ju}, \mathrm{Lu}, \mathrm{Sa}, \mathrm{Su}$.

\section{Buellia subdisciformis (Leighton) Vain.}

Etud. Lich. Brésil 7(1): 167 (1890).-Lecidea subdisciformis Leighton, Lich. Fl. Great Brit.: 308 (1871). Type: England, Caernavonshire, Conway Mountain, 1851, Leighton (BM!-lectotype).

Buellia ryssolea (Leighton) A. L. Smith, Monogr. Brit. Lich. 2: 173 (1911)._Lecidea ryssolea Leight., Trans. Linn. Soc. London, Ser. 2, Bot. 1: 237 (1878). Type: Fort Hill, near Fishguard, Pembrokeshire, Leighton (BM!-holotype).

B. sejuncta Steiner, Verh. zool. bot. Ges. Wien 57: 358 (1907). Type: circa Orri in Sard. merid., exempl. sinistrum (W!- holotype). 
Thallus often more than $5 \mathrm{~cm}$ diam., up to $1 \mathrm{~mm}$ thick, rimose to bullate, whitish, medulla not amyloid, I - . Apothecia lecideine, 0.5-1.2 mm diam., sessile with constricted base, disc plane to convex, sometimes \pm pruinose, margin thick and prominent. Exciple leptocline-type. Hymenium without oil droplets, $80 \mu \mathrm{m}$ high, epihymenium brown, hypothecium dark reddish brown. Ascospores oblong, constricted at septum, Physconia-type, 13-15 $\times 7-9 \mu \mathrm{m}$, ornamentation microrugulate. Conidia bacilliform, 9-14 $\mu \mathrm{m}$ long.

Chemistry: Atranorin and norstictic acid with connorstictic acid.

Taxonomy: Often grows with $H$. leptoclinoides, from which it differs in its thicker apothecial margin, lack of oil droplets in the hymenium, exciple-type and chemistry. The type of $B$. sejuncta is very poorly developed but appears similar to $B$. subdisciformis and also has similar conidia, but lacks norstictic acid. About one hundred specimens of $B$. sardiniensis and B. subdisciformis from Sardinia were chemically analysed and I never found a second specimen with the same characters as $B$. sejuncta. It is likely that $B$. sejuncta is possibly a very rare chemical strain of $B$. subdisciformis lacking norstictic acid.

Ecology and distribution: On maritime granitic rocks (Sheard 1964) and is widespread throughout the Mediterranean region as well as on the coasts in western Europe (map in Scheidegger 1991). European specimens have been studied from: $\mathrm{Br}, \mathrm{Bu}, \mathrm{Co}, \mathrm{Ga}, \mathrm{Gr}, \mathrm{Hb}, \mathrm{Hs}$, It, Lu, Sa, Si, Tu.

\section{Buellia subsquamosa Steiner}

Verh. zool. bot. Ges. Wien 57: 360 (1907), non sensu Buschardt (1979). Type: Tirol, Montan, Kernstock (W!-holotype).

Thallus verrucose to rimose, up to more than $1 \mathrm{~mm}$ thick, whitish, medulla slightly amyloid, I + violet. Apothecia lecideine, 0.5-0.8 mm diam., broadly sessile, disc plane, margin broad. Exciple aethalea-type. Hymenium without oil droplets, $65-85 \mu \mathrm{m}$ high, epihymenium olive to brown, hypothecium dark brown. Ascospores oblong, constricted at septum, Buellia-type, 13-16 ×6.5$5.8 \mu \mathrm{m}$, ornamentation microrugulate to rugulate. Conidia bacilliform, $5-7.5 \mu \mathrm{m}$ long.

\section{Chemistry: Atranorin, psoromic acid in a part of the samples}

Taxonomy: Differs from $B$. spuria in the absence of stictic and norstictic acids and by the somewhat longer spores. The two chemotypes, with and without psoromic acid, are considered here to be conspecific. If additional material shows that the two taxa should be separated, the name $B$. subsquamosa must be used for the taxon without psoromic acid.

Ecology and distribution: Probably a rare species on porous substrata rich in minerals in xerothermic habitats from the inner alpine dry valleys to the Mediterranean region. European specimens have been studied from: $\mathrm{Ga}, \mathrm{Gr}$, It, Hs, Lu, Sa. 


\section{Buellia tesserata Körber}

Parerg. Lich.: 189 (1860). Type: An Schieferfelsen Norwegens von Hübener und Kurr gesammelt (L!-holotype, UPS!-isotype).

Prothallus black, fimbriate, thallus areolate, whitish, medulla not amyloid, I-. Apothecia cryptolecanorine, 0.3-0.5 mm diam., innate, disc convex. Exciple aethalea-type. Hymenium without oil droplets, $60 \mu \mathrm{m}$ high, epihymenium brown, hypothecium dark brown. Ascospores oblong, constricted at septum, Buellia-type, 9-11 $\times 5-6 \mu \mathrm{m}$, ornamentation rugulate. Conidia not found.

\section{Chemistry: Barbatic acid.}

Taxonomy: Closely resembles $B$. fimbriata from which it differs only in chemistry. Buellia fimbriata is restricted to the Mediterranean area and its occurrence in Norway would be very surprising. Therefore the two taxa are treated as separate species. It is hoped that more material of $B$. tesserata will be found in the future to permit a more detailed discussion of the relationship of the two taxa.

Ecology and distribution: Known only from the type locality. The type collection may be erroneously labelled.

\section{Buellia tirolensis Körber}

Parerg. Lich.: 460 (1860). Type: Naifthale bei Meran, Bamberger, (UPS!-isotype).

Buellia buellioides (Metzler in Arnold) Buschardt, Bibl. Lich. 10: 86 (1979).—Rinodina buellioides Metzler in Arnold, Verh. zool. bot. Ges. Wien 23: 112 (1873) nomen novum pro Buellia fusca Arnold, Verh. zool. bot. Ges. Wien 22: 291 (1872). Type: An Blöcken ober Gries, Arnold (M!holotype).

Lecidea luridula Nyl., Flora, Jena 56: 202 (1873), Bull. Soc. Linn. Normandie, Sér. 2, 6: 312 (1873). Type: France, Pyrénées orientales, Collioure. 4 August 1872, W. Nylander (H-NYL 9216 !- holotype).

Lecidea scotochroa Nyl., Flora, fena 68: 297 (1885). Type: France, Pyrénées orientales, Amélie, saxicola ad nosocom. militare, infra saxa calcarea super saxa schistosa, 22 July 1884, W. Nylander (H-NYL 9328!- holotype).

Buellia cinereomarginata B. de Lesd., Bull. Soc. Bot. France 70: 281 (1923). Type: France, Var, Massif des Maurettes, June 1923, $A$. de Crozals (UPS!-isotype).

Thallus areolate, brown, shiny, areolae often with narrow whitish margin. Medulla not amyloid, I-. Apothecia cryptolecanorine, $0.2-0.4 \mathrm{~mm}$ diam., innate. Exciple aethalea-type. Hymenium without oil droplets, $40-65 \mu \mathrm{m}$ high. Epihymenium brown, hypothecium light brown. Ascospores broadly oblong, not constricted at septum, Buellia-type, 9-11 $\times 5.5-7 \mu \mathrm{m}$, ornamentation psilate. Pycnidia found in one specimen, but no conidia found.

Chemistry: Norstictic acid with connorstictic acid.

Taxonomy: In morphology similar to B. fusca, from which it mainly differs in chemistry. A detailed analysis of this species must follow when North American species such as $B$. novomexicana are considered. 
Ecology and distribution: On siliceous boulders in xerothermic areas in the Mediterranean and southern central European region (map in Scheidegger 1991). European specimens have been studied from: $\mathrm{Ga}, \mathrm{He}, \mathrm{Hs}, \mathrm{It}, \mathrm{Sa}, \mathrm{Tu}$.

\section{Buellia uberior Anzi}

Atti Soc. Sci. Nat. 9: 252 (1866). Type: Italy, Lombardia, Alpe Braulio, valle Zebru, Anzi (M!lectotype; H-NYL 9321!--isotype).

See Scheidegger (1987).

Prothallus often present, thallus greyish, shiny, medulla amyloid, I + violet. Apothecia cryptolecanorine to zeorine, $0 \cdot 2-0 \cdot 8 \mathrm{~mm}$ diam., innate. Exciple aethalea-type. Hymenium without oil droplets, $42-68 \mu \mathrm{m}$, high, epihymenium green to olive, hypothecium hyaline to light brown. Ascospores broadly oblong, constricted at septum, Buellia-type, $8.1-11.7 \times 4.7-6.4 \mu \mathrm{m}$, ornamentation striate. Conidia bacilliform, 3.5-4 $\mu \mathrm{m}$ long.

Chemistry: Gyrophoric acid, stictic acid in a part of the samples

Taxonomy: The species may easily be recognized by the striate ornamentation of the spores; it resembles $B$, miriquidica and $B$. uberiuscula.

Ecology and distribution: An alpine species growing on wind-exposed, siliceous rocks (map in Scheidegger 1987). Buellia uberior often grows as a lichenicolous lichen on Schaereria fuscocinerea. European specimens have been studied from: $\mathrm{Au}, \mathrm{Br}, \mathrm{Cz}, \mathrm{Ga}, \mathrm{Ge}, \mathrm{He}, \mathrm{Hs}, \mathrm{It}, \mathrm{Lu}, \mathrm{No}, \mathrm{Rs}, \mathrm{Sa}, \mathrm{Su}$.

\section{Buellia uberiuscula (Nyl.) Zahlbr.}

Cat. Lich. Univ. 7:426 (1931).-Lecidea uberiuscula Nyl., Flora, fena 56: 75(1873), Bull. Soc. Linn. Normandie Ser. 2, 6: 279 (1873). Type: Pyrénées-orientales, Costabonne, $2000 \mathrm{~m}$ alt, 13 July 1872, W. Nylander (H-NYL!-holotype).

Thallus small, few areolae, grey, matt, medulla amyloid, I + violet. Apothecia cryptolecanorine to zeorine, $0 \cdot 3-0.4 \mathrm{~mm}$ diam., innate. Exciple aethalea-type. Hymenium without oil droplets, c. $80 \mu \mathrm{m}$ high, epihymenium brown, hypothecium hyaline. Ascospores broadly oblong, Buellia-type, $12.5-15 \times 7-9 \mu \mathrm{m}$, ornamentation microrugulate. Conidia not seen.

\section{Chemistry: Norstictic acid with connorstictic acid.}

Taxonomy: Buellia uberiuscula is closely related to $B$. aethalea. The main differences are the very small thalli consisting only of a few areolae and the biology of this lichenicolous lichen, often growing on Acarospora fuscata.

Ecology and distribution: Grows in nutrient-rich habitats on granite substrata in the alpine zone. European specimens have been studied from: $\mathrm{Au}, \mathrm{Ga}, \mathrm{He}$, Hs. 


\section{Buellia vilis Th. Fr.}

Kgl. Vetensk. Akad. Handl. 7(2): 44 (1867). Type: Sualbard, ad saxa litore occidentali, Nordenskjöld (Type not seen).

Lecidea disciformis var. enteroleucoides Nyl., Flora, Jena 52: 298 (1869). Type: Islandia, 1868, Chr. Groenlund (H-NYL 10454!-isotype).

Buellia modica (Nyl.) Migula, Flora von Deutschland II: 75 (1929)._-Lecidea modica Nyl., Flora, fena 58: 301 (1875). Type: Haute-Vienne, Lamy (H-NYL 9231!-holotype).

Thallus chasmolithic, hyphae strongly amyloid, I+ violet. Apothecia lecideine, $0 \cdot 15-0.6 \mathrm{~mm}$ diam., sessile, constricted at base, disc plane to slightly convex, margin broad, persistent. Exciple vilis-type. Hymenium without oil droplets, $c .80 \mu \mathrm{m}$ high, epihymenium brown, hypothecium hyaline, strongly amyloid. Ascospores broadly oblong, slightly constricted at septum, Buelliatype, $12-15 \times 7 \cdot 5-9 \mu \mathrm{m}$, ornamentation psilate to microrugulate. Conidia bacilliform, $2 \cdot 5-4 \mu \mathrm{m}$ long.

Chemistry: No substances found.

Taxonomy: Resembles $B$. sequax, also with a chasmolithic thallus but differs in the structure of the exciple, broader spores and ecology. Buellia vilis is the only species with this particular exciple anatomy and seems to be taxonomically isolated in the genus.

Ecology and distribution: On small pebbles in very wind-exposed habitats in the alpine region (Poelt 1960) and on recently eroded surfaces of granitic boulders (Scheidegger 1991). European specimens have been studied from: $\mathrm{Au}, \mathrm{Ga}, \mathrm{Gr}, \mathrm{He}, \mathrm{Hs}$, Is, It, Ju, No, Su.

\section{Hafellia}

\section{Hafellia leptoclinoides (Nyl.) Scheidegger \& Mayrh. in Kalb}

Lich. Neotrop. Fasc. 9: 9 (1986).-Lecidea leptoclinoides Nyl., Bull. Soc. Linn. Normand., ser. 2, 6: 311 (1872). Type: France, Pyrénées-orientales, Port-Vendres 6 July 1887, Nylander (H-NYL 10541 !--lectotype).

Thallus often $>5 \mathrm{~cm}$ diam., rimose to bullate, whitish to yellowish, medulla not amyloid, I- . Apothecia lecideine, 0.4-1 mm diam., sessile with a constricted base. Disc plane to convex, margin thin, prominent. Exciple textura oblita, the outer part of textura angularis, similar to dispersa-type, differing mainly in the presence of crystal complexes (up to $20 \mu \mathrm{m}$ diam.) in the outer part of the exciple. Hymenium with oil droplets, $70-95 \mu \mathrm{m}$ high, epihymenium brown, hypothecium dark brown. Ascospores callispora-type, 16-18 $\times 7$ $9.5 \mu \mathrm{m}$, ornamentation psilate. Conidia bacilliform, 5-6 $\mu \mathrm{m}$ long.

Chemistry: Atranorin, placodiolic acid.

Taxonomy: Differs from B. excelsa in the presence of placodiolic acid and the different spore type. Hafellia leptoclinoides is the only species of this genus with placodiolic acid. Other species such as $H$. bispora Sheard, $H$. callispora (Knight) Mayrh. \& Sheard, H. fosteri Imsh. \& Sheard and H. parastata (Nyl.) 
Kalb have atranorin and diploicin; H. bahiana (Malme) Sheard has norstictic acid (Sheard 1992). Birbeck et al. (1990) reported diploicin, isofulgidin and atranorin for the related Rinodina dissa (Stirton) Mayrh.

Ecology and distribution: Mainly on horizonal to vertical schists on coastal rocks from the Mediterranean to the west European coasts (map in Scheidegger 1991); the species is also reported from North Africa (Algeria, Morocco). European specimens have been studied from: $\mathrm{Br}, \mathrm{Co}, \mathrm{Ga}, \mathrm{Gr}, \mathrm{Hs}$, It, Lu, Sa.

My sincerest thanks go to Dr K. Ammann, Dr H. Mayrhofer and Prof. J. Poelt for their encouragement during my lichenological studies. 3-Chlorodivaricatic acid was kindly identified by Prof. C. Leuckert and Prof. S. Huneck. Dr P. Geissler helped with the Latin diagnoses. Mr P. W. James, Dr B. Coppins and two anonymous referees discussed the manuscript in detail and made many valuable comments. I am much indebted to the curators and owners of the herbaria listed in Materials and methods. I also thank Mrs F. Oberli, Mrs D. Pichler and Mr P. Sulser for technical assistance, Mrs $\mathrm{Ch}$. Keller and Mr M. Dietrich for some TLC analyses, and Dr. P. Clerc for stimulating discussions. The publication of this study was financially supported by the Swiss Federal Institute for Forest, Snow and Landscape Research.

\section{REFERENCES}

Aptroot, A. (1987) (871) Proposal to conserve Buellia De. Not. against Gassicurtia Fée (Lichenized Fungi, Pyxinaceae). Taxon 36(2): 474.

Bellemère, A. \& Letrouit-Galinou, M.-A. (1987) Differentiation of lichen asci including dehiscence and sporogenesis: an ultrastructural survey. Bibliotheca Lichenologia 25: 137-161.

Birbeck, A., Sargent, M. \& Elix, J. (1990) The structure of the depsidones fulgidin and isofulgidin. Australian fournal of Chemistry 43: 419-425.

Buschardt, A. (1979) Zur Flechtenflora der inneralpinen Trockentäler unter besonderer Berücksichtigung des Vinschgaus. Bibliotheca Lichenologica 10: 1-419.

Choisy, M. (1950) Catalogue des lichens de la région Lyonnaise. Bulletin de la Société Linnéenne de Lyon 19: 9-24.

Coppins, B. (1983) A taxonomic study of the lichen genus Micarea in Europe. Bulletin of the British Museum (Natural History) Botany series 11(2): 17-214.

Culberson, Ch. F. \& Ammann, K. (1979) Standardmethode zur Dünnschichtchromatographie von Flechtensubstanzen. Herzogia 5: 1-24.

Culberson, C. F., Culberson, W. L. \& Johnson, A. (1981) A standardized TLC analysis of $\beta$-orcinol depsidones. Bryologist 84: 16-29.

De Notaris, G. (1846) Frammenti lichenographici di un lavoro inedito. Parlatore, Giornale Botanico Italiano 2: 174-224.

Egan, R. (1987) A fifth checklist of the lichen-forming, lichenicolous and allied fungi of the continental United States and Canada. Bryologist 90: 77-173.

Erdtman, G. (1943) An introduction to pollen analysis.: Waltham, Mass,: Chronica Botanica Company.

Erdtman, G. (1956) "LO-analysis" and "Welcker's rule", a centenary. Svensk Botanisk Tidskrift 50: 135-141.

Erichsen, C. F. E. (1930) Die Flechten des Moränengebietes von Ostschleswig mit Berücksichtigung der angrenzenden Gebiete. Verhandlungen des Botanischen Vereins der Provinz Brandenburg 72: $1-68$.

Erichsen, C. F. E. (1957) Flechtenflora von Nordwestdeutschland. Stuttgart: Gustav Fischer.

Fée, A. L. A. (1824-25) Essai sur les cryptogames des écorces exotiques officinales. Paris: Firmin Didot. Fries, Th. M. (1860) Lichenes Arctoi Europae Groenlandiaeque hactenus cogniti. Uppsala: C.A. Leffler.

Galloway, D. J. (1985) Flora of New Zealand Lichens. Wellington: P. D. Hasselberg, N.2. Government Printer.

Grummann, V. (1963) Catalogus lichenum Germaniae. Stuttgart: Gustav Fischer.

Hafellner, J. (1979) Karschia. Revision einer Sammelgattung an der Grenze von lichenisierten und nichtlichenisierten Ascomyceten. Nova Hedwigia, Beihefte 62. Vaduz: Cramer. 
Hafellner, J., Mayrhofer, H. \& Poelt, J. (1979) Die Gattungen der Flechtenfamilie Physciaceae. Herzogia 5: 39-79.

Hawksworth, D. L., Sutton, B. C. \& Ainsworth, G. C. (1983) Ainsworth and Bisby's Dictionary of the Fungi 7 th edn. Kew: Commonwealth Mycological Institute.

Hessen, A. \& Jahns, H. M. (1973) ['1974'] Lichenes; eine Einführung in die Flechtenkunde. Stuttgart: Thieme.

Holmgren, P. K., Holmgren, N. H. \& Barnett, L. C. (1990) Index Herbariorum, Part I: The Herbaria of the World, New York: New York Botanical Garden.

Honegger, R. (1978a) Licht-und elektronenmikroskopische Untersuchungen an Flechten-Asci vom Lecanora-Typ. Dissertation, University of Basel.

Honegger, R. (1978b) The ascus apex in lichenized fungi I. The Lecanora-, Peltigera- and Teloschistes-types. Lichenologist 10: 47-67.

Imshaug, H. A. (1951) The lichen-forming species of the genus Buellia occurring in the United States and Canada. Ann Arbor: University Microfilms.

Imshaug, H. A. (1955) The lichen genus Buellia in the West Indies. Farlowia 4(4): 473-512.

Kalb, K. (1986) Lichenes Neotropici, Fasc. 9. Neumarkt: Klaus Kalb.

Kilias, H. (1981) Revision gesteinsbewohnender Sippen der Flechtengattung Catillaria Massal. in Europa. Herzogia 5: 209-448.

Korf, R. P. (1973) Discomycetes and Tuberales. In The Fungi; IV A. A taxonomic treatment with keys. Ascomycetes and fungi imperfecti (G. C. Ainsworth, F. K. Sparrow \& A. S. Sussmann, eds): 249-319. New York: Academic Press.

Körber, G. W. (1855) Systema Lichenum Germaniae. Breslau: Trewendt \& Granier.

Kremp, G. O. W. (1968) Morphologic encyclopedia of palynology. Tucson: University of Arizona Press.

Lamb, M. (1968) Antarctic lichens II. The genera Buellia and Rinodina. British Antarctic Survey, Scientific Reports 61: 1-129.

Leuckert, Ch. (1984) Die Identifizierung von Flechtenstoffen im Rahmen chemotaxonomischer Routineanalysen. Nova Hedwigia, Beihefte 79: 839-869.

Leunis, J. (1877) Synopsis der Pflanzenkunde, 2. edn. Hannover: Hahn.

Llimona, X., Werner, R. G., Lallemant, R. \& Boissière, J. C. (1976) A propos du Buellia subcanescens R. G. Werner, espèce primaire du Buellia canescens (Dicks.) D. N. Revue bryologique et lichénologique 42: 617-635.

Magnusson, A. H. (1955) Key to saxicolous Buellia species, mainly from South America. Arkiv för Botanik 3(9): 205-221.

Massalongo, A. (1852) Ricerche sull' autonomia dei licheni crostosi e materiali pella loro naturale ordinazione. Verona: Frizierio.

Matzer, M., Mayrhofer, H. \& Scheidegger, C. (1994) Notes on Amandinea petermannii comb. nov. (Physciaceae, lichenized ascomycetes) from Antarctica. Lichenologist (in press).

Mayrhofer, H. (1982) Ascosporen und Evolution der Flechtenfamilie Physciaceae. Fournal of the Hattori Botanical Laboratory 52: 313-321.

Mayrhofer, H. (1984a) Die saxicolen Arten der Flechtengattung Rinodina und Rinodinella in der alten Welt. Fournal of the Hattori Botanical Laboratory 55: 327-493.

Mayrhofer, H. (1984b) The saxicolous species of Dimelaena, Rinodina and Rinodinella in Australia. Nova Hedwigia, Beiheft 79: 511-536.

Mayrhofer, H. \& Poelt, J. (1979) Die saxicolen Arten der Flechtengattung Rinodina in Europa. Bibliotheca Lichenologica 12: 1-186.

Mayrhofer, H., Scheidegger, C. \& Sheard, J. W. (1992) On the taxonomy of five saxicolous species of the lichenized ascomycete genus Rinodina. Nordic Fournal of Botany 12: 451-459.

Moberg, R. (1977) The lichen genus Physcia and allied genera in Fennoscandia. Symbolae Botanicae Upsaliensis 22(1): 1-108.

Müller, E. \& von Arx, J. A. (1962) Die Gattungen der didymosporen Pyrenomyceten. Beiträge zur Kryptogamenflora der Schweiz 11(2): 1-922.

Poelt, J. (1958) Die lobaten Arten der Flechtengattung Lecanora Ach. sensu ampl. in der Holarktis. Mitteilungen der Botanischen Staatssammlung München 2: 411-573.

Poelt, J. (1960) Mitteleuropäische Flechten VI. Mitteilungen der Botanischen Staatssammlung München 3: 568-584.

Poelt, J. (1973) Classification. In The Lichens (V. Ahmadjian \& M. E. Hale, eds): 599-632. New York: Academic Press. 
Poelt, J. (1989) Die Entstehung einer Strauchflechte aus einem Formenkreis krustiger Verwandter. Flora, Fena 183: 65-72.

Poelt, J. \& Mayrhofer, H. (1979) Studien über Ascosporen-Typen der Flechtengattung Rinodina. Beihefte zur Sydowia Annales Mycologici 8: 312-331.

Poelt, J. \& Sulzer, M. (1974) Die Erdflechte Buellia epigaea, eine Sammelart. Nova Hedwigia 25: 173-194.

Ruef, B. (1990) Massenspektrometrische Untersuchungen an Flechtenxanthonen. Dissertation, University of Bern.

Schauer, T. (1965) Die holz-und rindenbewohnenden Arten der Flechtengattung Buellia s.str. im Nordalpenraum. Mitteilungen der Botanischen Staatssammlung München 5: 609-626.

Scheidegger, C. (1987) Buellia uberior und B. miriquidica (Physciaceae, Lecanorales), zwei lichenicole Krustenflechten auf Schaereria tenebrosa. Botanica Helvetica 97: 99-116.

Scheidegger, C. (1988) Beiträge zu einer Revision gesteinsbewohnender Sippen der Flechtengattung Buellia De. Not. in Europa. Bern: Gnägi's Druck-Egge.

Scheidegger, C. (1991) Phytogeography of the lichen genus Buellia (Physciaceae, Lecanorales) in Mediterranean Europe. Botanika Chronika 10: 211-220.

Scheidegger, C. \& Ruef, B. (1988) Die xanthonhaltigen, gesteinsbewohnenden Sippen der Flechtengattung Buellia De Not. in Europa. Nova Hedwigia 47: 433-468.

Sheard, J. W. (1964) The genus Buellia in the British Isles. Lichenologist 2: 225-262.

Sheard, J. W. (1992) The lichenized ascomycete genus Hafellia in North America. Bryologist 95: 79-87.

Singh, S. R. \& Awasthi, D. (1981) The lichen genus Buellia in India. Biological Memoirs 6: 169-196.

Steiner, J. (1907) Ueber Buellia saxorum und verwandte Flechtenarten. Verhandlungen der k.k. zoologisch-botanischen Gesellschaft Wien 57: 340-371.

Triebel, D. (1987) Was ist Lecidea whakatipae Knight? Mitteilungen der Botanischen Staatssammlung München 23: 343-344.

Tutin, T. G., Heywood, V. H., Burges, N. A., Valentine, D. H., Walters, S. M. \& Webb, D. A. (1964) Flora Europaea, Vol. I. Cambridge: Cambridge University Press.

Vainio, E. (1890) Etude sur la classification naturelle et la morphologie des lichens du Brésil I. Acta Societatis pro Fauna et Flora Fennica 7(1): 1-247.

Vobis, G. \& Hawksworth, D. L. (1981) Conidial lichen-forming fungi. In The Biology of Conidial Fungi (G. T. Cole \& B. Kendrick, eds): 245-273. New York: Academic Press.

White, F. J. \& James P. W. (1985) A new guide to microchemical techniques for the identification of lichen substances. British Lichen Society Bulletin 57(suppl.): 1-41.

Zahlbruckner, A. (1907/1926) Lichenes. In Die Natürlichen Pflanzenfamilien (A. Engler \& K. Prantl, eds): $B d$. 8. Leipzig: Borntraeger.

\section{Accepted for publication 24 April 1992}

